\title{
Consequences of Financial Reporting Failure for Outside Directors: Evidence from Accounting Restatements and Audit Committee Members
}

\section{Citation}

Srinivasan, Suraj. "Consequences of Financial Reporting Failure for Outside Directors: Evidence from Accounting Restatements and Audit Committee Members." Journal of Accounting Research 43, no. 2 (May 2005): 291-334.

\section{Published Version}

10.1111/j.1475-679x.2005.00172.x;http://onlinelibrary.wiley.com/doi/10.1111/

j.1475-679x.2005.00172.x/abstract

\section{Permanent link}

http://nrs.harvard.edu/urn-3:HUL.InstRepos:29660924

\section{Terms of Use}

This article was downloaded from Harvard University's DASH repository, and is made available under the terms and conditions applicable to Other Posted Material, as set forth at http:// nrs.harvard.edu/urn-3:HUL.InstRepos:dash.current.terms-of-use\#LAA

\section{Share Your Story}

The Harvard community has made this article openly available.

Please share how this access benefits you. Submit a story.

Accessibility 


\title{
Consequences of Financial Reporting Failure for Outside Directors: Evidence from Accounting Restatements and Audit Committee Members
}

\author{
Suraj Srinivasan*
}

December 2004

\section{Forthcoming}

Srinivasan, S. 2005. Consequences of financial reporting failure for outside directors: Evidence from accounting restatements. Journal of Accounting Research 43 (May): 291334.

* The University of Chicago. I would like to thank my dissertation committee: Paul Healy, Krishna Palepu, and Greg Miller for their invaluable guidance and support. I have greatly benefited by comments and suggestions from Kristen Andersen, George Baker, Ray Ball, Dennis Campbell, Srikant Datar, Paul Gompers, S.P. Kothari, Rainier Kraakman, Jay Lorsch, V.G. Narayanan, Edward Riedl, Mark Roe, Susan Scholz, Franco Wong, Min Wu, workshop participants at Columbia University, University of Chicago, Harvard University, Kellogg, MIT, Stanford University, University of Texas-Austin, Wharton School, and the 2004 Journal of Accounting Research conference, as well as from Abbie Smith (editor), an anonymous referee, and Scott Richardson (discussant). I am grateful to Asis Martinez-Jerez and Greg Miller for some of the data used in this study. Orice Williams at the General Accounting Office, Scott Reed at the KPMG Audit Committee Institute, audit partners at another Big-4 firm, Charles King at Korn-Ferry, and Ted Jaedick at Heidrich and Struggles provided useful insights that have greatly improved this paper. I also thank Xiaohui Chang, Lee Gao, Vivian Li, and Yue Zhou for excellent research assistance. I gratefully acknowledge the financial support of the University of Chicago GSB, the Deloitte Foundation, the Harvard Business School, and the George S. Dively Award. 


\title{
Consequences of Financial Reporting Failure for Outside Directors: Evidence from Accounting Restatements and Audit Committee Members
}

\begin{abstract}
I use a sample of 409 companies that restate their earnings in 1997-2001 to examine penalties for outside directors, particularly audit committee members, when their companies experience accounting restatements. Penalties from lawsuits and Securities Exchange Commission (SEC) actions are limited. However, directors experience significant labor market penalties. In the three years after the restatement, director turnover is $48 \%$ for firms that restate earnings downward, 33\% for a performancematched sample, $28 \%$ for firms that restate upwards, and only $18 \%$ for technical restatement firms. For firms that overstate earnings, the likelihood of director departure increases in restatement severity, particularly for audit committee directors. In addition, directors of these firms are no longer present in $25 \%$ of their positions on other boards. This loss is greater for audit committee members and for more severe restatements. A matched-sample analysis also confirms this result. Overall, the evidence is consistent with outside directors, especially audit committee members, bearing reputational costs for financial reporting failure.
\end{abstract}




\section{Consequences of Financial Reporting Failure for Outside Directors: Evidence from Accounting Restatements and Audit Committee Members}

\section{Introduction}

Recent accounting scandals raise questions about the role of the board and the audit committee in monitoring financial reporting. Regulators have responded with governance reforms that attempt to enhance the role of outside directors in financial reporting oversight. ${ }^{1}$ Although academic research has extensively studied the relationship between board independence and financial reporting, little is known about the consequences of financial reporting failure for outside directors. In this study I examine legal and reputational penalties for outside directors, particularly those on the audit committee, when their companies experience financial reporting failure.

Fama and Jensen [1983] and Lorsch and MacIver [1989] argue that the primary benefits from board membership for outside directors are prestige, reputation, learning opportunities, and networking. In an efficient director labor market, directors who perform their board functions effectively are likely to be rewarded with additional board appointments and benefits; those who perform poorly will be penalized by loss in their positions and benefits.

Prior research suggests that directors are held accountable for corporate failures (e.g., bankruptcy) because board turnover increases following these events (e.g., Gilson [1990]). However, there is no evidence on whether there are penalties for outside directors for financial reporting failure. A priori, it is unclear whether directors should be

\footnotetext{
${ }^{1}$ Outside directors are those board members who have no relationship with the company other than their role as directors. They are also sometimes referred to as independent directors. Other directors are classified as Insiders and affiliated (or grey) directors. Insiders are executives of the company. Affiliated directors are those with potential conflicts of interests. The conflicts can include consulting arrangements, family relationship, and interlocking board memberships.
} 
held accountable for these events. Boards are certainly responsible for overseeing the firm audit and adequacy of internal controls. Financial reporting problems are typically material events for the firm, as shown by the large negative stock market reactions to their announcement. Furthermore, there is some evidence that the likelihood of financial reporting problems can be diminished with greater independence and expertise on boards and audit committees (Beasley [1996], Dechow, Sloan, and Sweeney [1996], Farber [2004], Agarwal and Chadha [2003]). However, because outside directors depend on managers and auditors for information they may be in no position to second-guess the external or internal auditor, or to detect management fraud. Academic studies examining board accountability are generally hampered by the lack of performance measures for individual directors because boards function as a composite entity. In this study I attempt to deconstruct board performance by using accounting failures as a performance measure to evaluate audit committee directors who are directly responsible for monitoring financial reporting and to compare them with non-audit committee directors who may bear lesser responsibility for the failure.

I use a sample of 409 companies that announced restatements in 1997 to 2001 to provide evidence on the labor market penalties for outside directors, particularly audit committee members, from financial reporting problems. Three different types of restatements are identified and examined separately: income-decreasing, incomeincreasing, and technical restatements. The occurrence of a restatement implies not only that an irregularity occurred but also that it was detected. Because audit committees monitor the system within which the irregularities are both committed and detected, a restatement does not necessarily imply audit committee failure. Responsibility for 
commission implies audit committee failure whereas detection implies audit committee effectiveness. I use the severity of the restatement to proxy for the extent of monitoring failure, as restatements of greater severity are more likely to represent audit committee failure than less severe restatements.

The primary analysis examines director turnover and loss in other board positions for audit committee directors compared with other outside directors for the incomedecreasing restatements sample. Non-audit committee directors provide a powerful matched sample because they belong to the same company but are not directly responsible for financial reporting. The income-decreasing restatements sample consists of 264 companies (with 1,272 outside directors). I then examine the income-increasing and technical restatement samples. The income-increasing sample consists of 332 directors in 69 companies, and the technical restatements sample consists of 412 directors in 76 companies. Finally, to provide a benchmark of non-restating firms I create a non restatement sample of companies matched by industry, year, and performance for all the 264 income-decreasing restatement companies. I conduct a differences-in-differences estimation by comparing the turnover and loss in other directorships for the audit committee members relative to non audit committee directors in the income-decreasing restatement sample to the same difference in the non restating companies. I also repeat this analysis for a subset of 51 pairs where both the restatement and matched sample experienced CEO turnover, thereby matching on firm performance and CEO turnover.

Penalties are strongest for outside directors of the income-decreasing restatements sample. These restatements are followed by abnormally high board turnover, with $48.1 \%$ of outside directors turning over within three years of the restatement announcement 
compared to a turnover of only $14 \%$ in the three years prior to the restatement. ${ }^{2}$ The likelihood of director turnover increases with the severity of the restatement and is greater for audit committee members than for other directors. Following the restatement, directors of these companies also lose board positions in other companies. This loss is greater for audit committee directors, for more severe restatements, and for directors who leave the restating company. The analysis controls for the effect of firm performance since poor performance could also contribute to the observed turnover.

Compared to the income-decreasing sample, companies making restatements that increase reported income exhibit a significantly lower turnover of $27.8 \%$ and a lower loss in other directorships. Within this sample, the likelihood of turnover is greater for the audit committee directors in firms with severe restatements, similar to income-decreasing restatements. However, estimates for some other variables are unstable between the models. Technical restatements (not misstatements and made for routine actions such as Financial Accounting Standards Board [FASB] pronouncements) have a turnover of only $18.6 \%$ and no significant change in other directorships. As expected, director turnover and loss in other directorships are not related to either the severity of the restatement or to audit committee membership. The matched-sample firms exhibit a lower director turnover rate (33\%) than income-decreasing restatements sample and a lower loss in other directorships. Compared to the directors in the control sample, audit committee directors of the income-decreasing restatement companies are more likely to turnover and lose other board positions than non-audit committee directors. This result is further

\footnotetext{
${ }^{2}$ Yermack [2003] finds a 4.6\% annual unconditional turnover rate for his sample of directors from Fortune 500 companies between 1994 and 1996.
} 
confirmed for the sub sample where both the restating and matched firm experience CEO turnover.

In contrast to the preceding evidence on career consequences, I find that outside directors face little discipline through regulatory actions or private litigation. The Securities and Exchange Commission (SEC) does not cite outside directors when it pursues enforcement action against the restating company and its managers. Securities class action litigation against outside directors is also limited. Only 78 of the 2,016 directors are named as defendants in lawsuits (of which 68 are from the 1,272 directors in the income-decreasing sample). Audit committee members are no more likely to be sued than other outside directors. Content analysis of the lawsuits shows that outside directors are likely to be sued only when they sell shares during the misstatement period. Moreover, in all cases where the lawsuit settlement information is available, the directors (and managers) do not pay any portion of the settlement, which is typically paid by the company and its insurance provider. These results show that outside directors do not face direct legal liability for poor monitoring of financial reporting. The market for directors appears to be the primary mechanism for holding directors responsible for financial reporting failure.

Overall, the results suggest that restatements are associated with labor market penalties for outside directors, particularly audit committee members. Although prior literature tends to interpret this as a reputational consequence, it could also be the result of directors voluntarily opting out of boards. Although the analysis cannot rule out voluntary departure as an explanation for the results, the evidence nevertheless has implications for our understanding of the incentives of outside directors and audit 
committee members. The evidence here is consistent with ex-post settling up in the market for directors. This may provide ex-ante incentives to motivate directors to be diligent in their oversight role.

The rest of the paper proceeds as follows. Section 2 discusses relevant prior literature, outlines the hypotheses, and develops the research design. Section 3 describes the sample, data collection, and descriptive statistics. Section 4 presents the results for own-board turnover and section 5 for loss in other board positions. Section 6 presents results with the control sample and robustness tests, section 7 discusses legal penalties and investor reaction, and section 8 concludes.

\section{Prior Literature, Hypotheses Development, and Research Design}

\subsection{Restatements}

I use earnings restatements to identify financial reporting failure for the following reasons. ${ }^{3}$ Restatements are an acknowledgement that prior financial statements were not in accordance with generally accepted accounting principles (GAAP) (Palmrose and Scholz [2004]). ${ }^{4}$ They indicate a breakdown in a firm’s internal control system (Kinney and McDaniel [1989]). Restatements have a material adverse effect on firm valuation. Palmrose, Richardson, and Scholz [2004] report a market reaction of $-9.2 \%$ to restatement announcements over a two-day $(0,1)$ window. $\mathrm{Wu}$ [2002] reports that earnings response coefficients decline following restatements, likely indicating a loss of

\footnotetext{
${ }^{3}$ Other studies that have used restatements as a proxy for financial reporting quality include Kinney, Palmrose, and Scholz [2003], Myers et al. [2003], Richardson et al. [2003], and Palmrose and Scholz [2004].

${ }^{4}$ Management has a legal duty to correct inaccurate filings. Skinner [1997, p. 252] quoting SEC guidelines, states, "there is a duty to correct statements made in any filing ... if the statements either have become inaccurate by virtue of subsequent events, or are later discovered to have been false and misleading from the outset, and the issuer knows or should know that persons are continuing to rely on all or any material portion of the statements.”
} 
confidence in the company's earnings quality. Hribar and Jenkins [2004] show that the firm's cost of capital increases following a restatement announcement.

Restatements can decrease reported income (income-decreasing) or increase reported income (income-increasing). Income-decreasing restatements suggest that prior accounting was aggressive, whereas income-increasing restatements, though still improper accounting, suggest either conservative accounting or "big-bath" behavior. Prior studies suggest that it is important to distinguish between these types of restatements (Callen, Linat, and Segal [2002], Myers et al., [2003]).

Restatements can also be technical in nature and not misstatements (Raghunandan, Read, and Whinesant [2003], Palmrose, Richardson, and Scholz [2004]). These arise from routine actions such as discontinued operations or FASB emerging issues task force rulings. Prior studies ignore these types of restatements. However, I examine them here as a form of benchmark sample.

\subsection{Boards and Financial Reporting}

My study focuses on outside directors, particularly those on the audit committee, because the academic literature and regulators emphasize the role of these directors in monitoring financial reporting. For example, in 1999, the New York Stock Exchange (NYSE) and NASDAQ modified their listing standards to require that firms maintain an audit committee with at least three outside directors. Recently, the Sarbanes-Oxley Act (2002) requires audit committees to be comprised entirely of independent directors, including at least one financial expert. 
Prior literature studies board and audit committee independence and its association with the quality of accounting. ${ }^{5}$ For example, Klein [2002] shows that independence in audit committees is negatively associated with the level of earnings management. Dechow, Sloan, and Sweeney [1996], Beasley [1996], and Farber [2004] report a greater percentage of insiders on boards using samples of SEC enforcement action companies. However, using a more recent sample of restatement firms, Agarwal and Chadha [2003] find no difference in the proportion of insiders compared to a matched sample. Some other results relating governance to accounting quality are mixed as well. Dechow, Sloan, and Sweeney [1996], Beneish [1999], and Agarwal and Chadha [2003] find no association between name-brand auditors and the likelihood of fraud. ${ }^{6}$ This contrasts with Farber [2004] who reports a smaller proportion of "name brand" audit firms in fraud firms compared to control firms but nevertheless finds that this difference persists for four years after fraud identification. With respect to audit committees, Farber finds that audit committees of fraud firms meet less frequently than control firms, a finding in contrast with Beasley [1996], who finds no such evidence in his sample. In contrast to this literature that examines the impact of boards on financial reporting outcomes, my study studies the impact of financial reporting failure on directors, particularly for those on the audit committee.

Prior studies find mixed evidence on top management turnover following detection of financial reporting fraud. Livingston [1997] finds that CEO turnover is more likely following SEC enforcement action than in other years. The departing CEOs are

\footnotetext{
${ }^{5}$ Larcker, Richardson and Tuna [2004] however, provide evidence of the modest ability of governance variables to explain managerial decisions and firm outcomes.

${ }^{6}$ I use the term "name brand" to refer to Big 6, Big 5 or Big 4 audit firms that these studies use as relevant to the time period of the particular study.
} 
unable to obtain similar positions at other exchange listed firms. Desai et al. [2004] find greater top management turnover than a matched sample and that $92 \%$ of the managers do not find comparable employment after departure. However, Beneish [1999] reports that CEO turnover after to discovery of income overstatement is no different from that of a control sample that do not overstate earnings. These studies focus on managers and do not examine consequences for boards and audit committees. Agarwal, Jaffe, and Karpoff [1999] find no association between occurrence of corporate fraud (in a sample that includes financial reporting fraud) and subsequent managerial or board turnover. Farber [2004] examines a sample of 87 firms subject to SEC enforcement action and presents univariate results showing that, compared to a matched sample, the fraud firms replace insiders with outside directors, but Farber does not comment on the composition of outsiders. The univariate comparisons also find an increase in the number of outsiders on the board and audit committee (statistical significance is not reported), but these are no different from the changes to the control sample. ${ }^{7}$ My study adds to this stream of literature by examining only outside directors, focusing on audit committee members. In addition, I study previously unexplored labor market reputational consequences as measured by the impact on other directorships for these directors.

\subsection{Market for Outside Directors}

My primary analysis examines labor market penalties—loss in position on the restating company’s board and loss in positions on other boards following a restatement. Board membership confers benefits to directors. Fama and Jensen [1983] suggest that

\footnotetext{
${ }^{7}$ Farber [2004] does not use performance as a matching attribute in creating the control sample nor is it controlled for in the analysis, thereby limiting the conclusions that can be drawn from the study because fraud firms are also likely to be poor performers. Prior literature suggests that board composition is affected by poor performance (Hermalin and Weisbach [1988]).
} 
outside directors are rewarded by the reputation they develop as expert monitors of managers. They argue that outside directors "use their directorships to signal to internal and external markets for decision agents that (1) they are decision experts...” (p. 315). Directors also gain from prestige, networking, and from learning opportunities when they serve on other boards. Such nonpecuniary rewards are typically considered more important than direct financial incentives (Mace [1986], Lorsch and MacIver [1989], Harford [2003]). ${ }^{8}$

An efficient director labor market will likely reward directors who have a reputation for effectiveness with additional board positions and associated benefits, and penalize the poor performers by loss of their positions and benefits. Fama and Jensen [1983] posit the existence of such a market and argue that directors face reputational penalties from ex post settling up in the labor market when monitoring is seen to fail. Directors may therefore have an ex-ante incentive to be efficient monitors. On the other hand, the costs of monitoring (e.g., talent, developing the required expertise, time) may result in director shirking.

Empirically, prior evidence is consistent with ex post settling up. Gilson [1990] finds that only $46 \%$ of incumbent directors remain after bankruptcy reorganization and that departing directors hold 33\% fewer other directorships after three years. Coles and Hoi [2003] provide evidence that directors of companies not adopting takeover protection

\footnotetext{
${ }^{8}$ Table 2.4 in Lorsch and MacIver [1989] lists the following personal benefits from board membership based on survey responses. In order of importance they are: opportunity to learn, seeing new businesses, establishing contacts to enhance business relationships, opportunity to contribute to society, and compensation.
} 
measures are three times more likely to gain additional directorships than directors of companies that protect themselves against takeovers. ${ }^{9}$

A priori, it is unclear whether director turnover will occur after a restatement. Audit committee directors could lose their positions for a few reasons. First, the audit committee, and to a lesser extent the entire board, is responsible for the oversight of audit and internal controls. Agarwal and Chadha [2004] find a smaller proportion of independent directors with an accounting background in restatement firms compared to a matched sample. Farber [2004] finds that fraud firms audit committees hold fewer meetings and fewer financial experts on them. This suggests a positive association between expertise on the audit committee and detection of accounting irregularities. ${ }^{10}$ The restatement can therefore indicate an oversight failure, creating a need for new audit committee directors to improve oversight. Second, restatements decrease firm value and lower the reputational capital of the firm. New directors may signal new leadership and bring with them fresh reputational capital. ${ }^{11}$ Third, restatements are often followed by CEO turnover, which has been shown to be associated with board turnover (Farrell and Whidbee [2000]). Finally, directors may leave voluntarily to avoid the responsibility and

\footnotetext{
${ }^{9}$ See also Kaplan and Reihsus [1990], Agarwal, Jaffe, and Karpoff [1999], Brickley, Coles, and Linck [1999], Farrell and Whidbee [2000], Ferris, Jagnnathan, and Pritchard [2003], Harford [2003], and Yermack [2003] for further evidence. There is also a large literature in organization behavior, strategy, and sociology on this aspect. I do not review this literature because of space limitations.

${ }^{10}$ As a caveat to this interpretation, Agarwal and Chadha [2003] and Farber [2004] find no difference in the number of outsiders on the audit committee between their treatment and control samples. Also, Farber finds that the difference in financial expertise on the audit committee between the sample and control firms persists for four years after fraud identification, raising the question of why fraud firms find no need to improve the audit committee on this dimension.

${ }^{11}$ For example, new directors at WorldCom include Nicholas B Katzenbach, former U.S. Attorney General and Dennis Beresford, former chairman of the FASB. Furthermore, Agarwal and Knoeber [2001] suggest that directors provide lobbying services for their firms to gain regulatory favors. This can be valuable when firms are under increased scrutiny.
} 
work involved with restructuring a troubled company (Vafeas [1999]) or to contain damage to their reputations. ${ }^{12}$

However, there are also reasons why we may not observe evidence of audit committee accountability. First, director responsibility is indirect since they only provide oversight and depend on managers and auditors for information. Consistent with this, Beasley [1996] finds that the presence of an audit committee does not affect the likelihood of fraud. Based on survey evidence of 250 non-executive directors, Hooghiemstra and Van Manen [2004] report that the directors express strong doubts about their ability to obtain timely and adequate information. ${ }^{13}$ Agarwal and Chadha [2003] find that the CFO serves on the audit committee in a statistically significant proportion of their control firms than in restating firms, suggesting a greater information flow to the audit committee in the former companies. Also consistent with this reasoning, courts and private litigants are rarely seen as holding outside directors accountable, allowing them latitude under the business judgment rule while holding managers responsible for the alleged infractions (Black, Cheffins, and Klausner [2003]). Second, because restatements require GAAP violations to be detected, it is not clear whether they represent success or failure by the audit committee. The cost associated with establishing pre emptive internal controls to eliminate all violations is likely prohibitive (Jensen [1993]). Good monitoring may identify the problem quickly and ensured timely disclosure. There is no reason to expect that effective directors will be replaced. Finally, entrenched boards are an important feature in companies (Bebchuk, Coates, and

\footnotetext{
${ }^{12}$ Companies rarely announce the reasons for director departure, making it difficult to discriminate between forced and voluntary departure.

${ }^{13}$ This is consistent with a recent Mckinsey survey that reports that most directors surveyed said that they depend on management to set the agenda of board meetings and few respondents felt that they really knew what was going on in their companies (Felton, Berrymand, and Stephenson [2004]).
} 
Subramanian [2002], Bebchuk and Cohen [2004]). For example, CEO-chair duality on boards is often used as a proxy for poor governance by extant literature. Prior literature observes prevalence of network ties and group norms in corporate boards (Davis and Greve [1997], Khurana [2002], Davis, Yoo, and Baker [2003]). Unlike managers, directors do not report to a higher authority that can easily replace them for poor performance (Yermack [2003]). Although in theory shareholders elect directors, in practice it is difficult to recall them. ${ }^{14}$ Therefore, it is remains an empirical issue as to whether directors would be held accountable for financial reporting failure.

Audit committee directors could also lose positions on other boards due to loss in reputation as an effective monitor. In addition to the preceding arguments, loss in other board positions also requires that the market for directors attribute the failure to poor oversight, use the information to infer directors' abilities, and act to penalize the director. However, the penalty may not manifest itself if the director has a track record of performance from other positions (e.g., CEO or director of another company). Alternatively, CEO's may prefer lax monitoring and find poor monitors attractive as candidates for their boards (Shivdasani and Yermack [1999]).

2.4 Hypotheses and Tests for Director Departure from the Restating Company Board.

If boards are accountable for reporting failure, the likelihood of director departure should depend primarily on the severity of the problem and the responsibility that specific directors bear for the failure. Restatement severity therefore serves as a proxy for the extent of monitoring failure. I assume that accountability for a reporting failure is higher for audit committee members than for other directors, as the board delegates to the

\footnotetext{
${ }^{14}$ Bebchuk [2002] provides a detailed overview of the process that illustrates the practical difficulty in dissident shareholders nominating new board members.
} 
audit committee the responsibility to monitor financial reporting. This results in the following two hypotheses (both stated in the alternative form):

H1: Turnover for outside directors is increasing in the severity of the restatement.

H2: Audit committee directors of restating firms experience a greater likelihood of turnover than other outside directors.

Following Palmrose, Richardson, and Scholz [2004], I measure severity of the restatement by its duration (number of quarters restated) and magnitude measured as the dollar value of cumulative change in net income (absolute values of restated less originally reported income) scaled by total assets at year-end immediately preceding to the restatement announcement. Duration measures the length of time the quality of accounting was compromised, while higher restatement magnitude indicates poorer prior representation of the actual numbers. I also classify restatements as interim or annual depending on whether the company restates quarterly financials (which are reviewed rather than audited) or the annual audited statements (Myers et al. [2003], Palmrose and Scholz [2004]). It may be that restating annual financials that have been subject to external audit are more indicative of poor control systems that restating interim un audited numbers.

To test the hypotheses, I model the probability of director departure as a function of restatement severity, audit committee status, and firm- and director-specific control variables using the following logit model. Table 1 provides definitions of the variables.

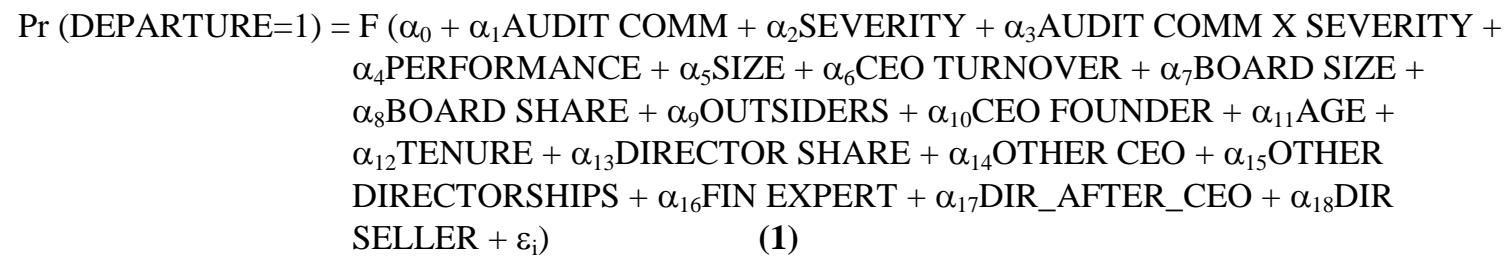


The dependent variable, DEPARTURE, equals 1 if the director leaves the board within three years of the restatement year. ${ }^{15}$ The main independent variables of interest are AUDIT COMM (an indicator variable that equals 1 if the director is on the audit committee, and 0 otherwise), SEVERITY (duration or scaled magnitude of the restatement), and AUDIT COMM X SEVERITY (the interaction of these two variables). Because restatements require the misstatement to be detected, it is possible that it indicates success rather than failure on the part of the audit committee. I include the interaction term to examine the possibility that restatements of lesser severity are either not informative about monitoring effectiveness or indicate effectiveness rather than failure.

Prior literature has found the following variable to be associated with director turnover: PERFORMANCE (Hermalin and Weisbach [1988], Gilson [1990], Yermack [2003]), SIZE (Ferris, Jagannathan, and Pritchard [2003]), and CEO TURNOVER (Farrell and Whidbee [2000]). I measure PERFORMANCE by the firm's stock returns because I expect it to best capture the effect of the restatement and revised expectation of future performance. Following Yermack [2003], PERFORMANCE is measured as the firm's stock return less the Center for Research in Security Prices (CRSP) value-weighted return, with both returns measured over the same time window as the dependent variable and compounded continuously before differencing. It is worth noting that because audit and non audit committee directors belong to the same firm, the effect of firm performance will apply equally to both (the estimates for the audit committee dummy are relative to nonaudit committee directors). SIZE is measured by total assets. CEO

\footnotetext{
${ }^{15}$ Many companies have staggered boards with each director serving a three-year term. In three years, therefore, every director would have had to come up for reelection. Because of this, most board turnover literature uses a three-year window to measure director turnover.
} 
TURNOVER equals 1 if CEO changes, and 0 otherwise. I include the variables board size, insider holding, and percentage of outsiders on the board to examine whether these governance characteristics are associated with turnover.

Director-level controls AGE, TENURE, DIRECTOR SHARE, and OTHER DIRECTORSHIPS are included to be consistent with prior literature referenced earlier. I include the variable FIN EXPERT to examine whether financial experts are more likely to be held accountable for the failure. DIR SELLER equals 1 if the director was a net seller in the company's stock during the misstatement period, and 0 otherwise.

\subsection{Hypotheses and Tests for Directorships in Other Companies}

If the restatement affects a director's reputation as an effective monitor, it could lead to a loss of positions on other boards. To examine this hypothesis, I estimate changes in the number of other board positions held by the directors. As before, the perception of poor oversight is likely to be increasing in the severity of the failure. Furthermore, as discussed earlier, the impact should be greater for audit committee members.

This results in the following two hypotheses (both stated in alternative form):

H3: Loss in other directorships is increasing in the severity of the restatement.

H4: Loss in other directorships for audit committee directors is greater than this loss for non-audit committee directors.

I model the loss in positions on other boards as a function of audit committee membership, restatement severity, and other firm and director level control variables.

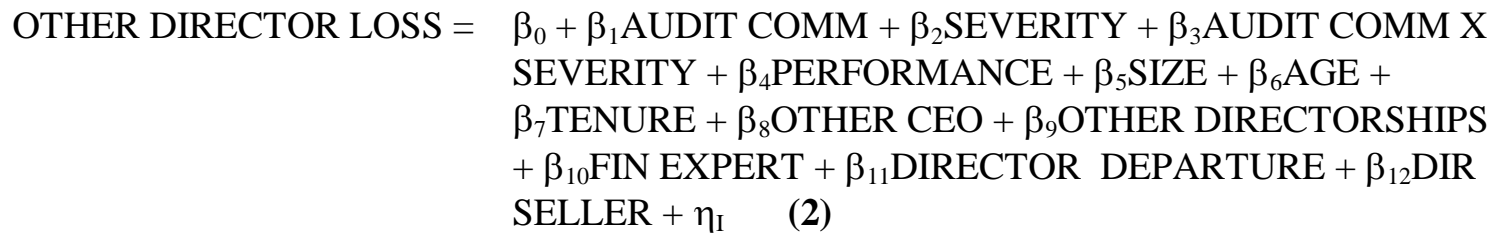


Table 1 provides definitions of all the variables. The dependent variable OTHER DIRECTOR LOSS measures the number of board positions lost by directors of restating companies in three years following the restatement. As in equation (1), the main independent variables are AUDIT COMM, SEVERITY, and AUDIT COMM X SEVERITY.

Firm level control variables are PERFORMANCE and SIZE. I include PERFORMANCE to control for the documented effect of firm performance on other directorships (Ferris, Jagannathan, and Pritchard [2003], Yermack [2003]). As mentioned previously, note that the effect of firm performance applies equally to audit and non-audit committee directors of the company. Director level controls are AGE, TENURE, OTHER CEO (which equals 1 if the director is the CEO of a public company), and OTHER DIRECTORSHIPS. I expect OTHER DIRECTORSHIPS to have a positive coefficient because directors with more positions are likely to lose more than those with fewer positions. Furthermore, directors that begin with zero positions cannot lose any seats. ${ }^{16}$ FIN EXPERT is included to examine whether the reputational penalty varies for financial experts. DIRECTOR DEPARTURE allows me to distinguish between directors who left the restating company board and those who continued.

\section{Sample}

\subsection{Restating Company Sample}

The sample consists of firms that announced restatements from 1997 to 2001 as provided in Government Accounting Office (GAO) [2002]. ${ }^{17}$ Table 2 explains the sample construction. The GAO database lists 794 companies, of which 11 companies did not

\footnotetext{
${ }^{16}$ I do not exclude these directors from the analysis since they can gain new directorships.

17 This dataset was created by the U.S. General Accounting Office as required by the Sarbanes-Oxley Act. Please refer GAO [2002] for details of the methodology used to create the database.
} 
eventually restate, 74 are multiple restatements by the same company (I include them only once), and 32 are foreign companies. I also drop companies for which I cannot collect the required data for the three years following the restatement announcement: 81 companies without CRSP or Compustat data and 187 companies stopped filing proxy statements or 10-Ks (needed to collect director data) because they delisted or merged.

My primary sample consists of the 264 companies that make income-decreasing restatements. However, I also examine separately the 69 income-increasing restatements and 76 technical restatements. Income-decreasing restatements suggest that the firm has followed aggressive accounting practices. Consequently, I expect my primary sample to provide the most powerful test of the hypotheses.

The relationship for the income-increasing sample is unclear. Although these are accounting failures, they may not be perceived to be as much of a failure as the incomedecreasing cases because they do not suggest aggressive accounting. The market reaction to restatements announcements confirms this conjecture. Mean (median) cumulative abnormal returns (CARs) over a two-day $(0,1)$ window around restatement announcements are $-4.7 \%(-4.6 \%)$ for income increasing cases versus $-13.1 \%(-7.4 \%)$ for income-decreasing restatements. Both are significant at the $1 \%$ level.

Technical restatements are not improper accounting. For this reason, prior research has typically ignored these companies (e.g., Raghunandan, Read, and Whinesant [2003], Palmrose and Scholz [2004]). Hence, this sample should not exhibit the hypothesized relationships. Consistent with this expectation, the mean (median) CAR for technical restatements at $-0.4 \%(-0.2 \%)$ is not different from zero. 
Table 3, Panel A provides the distribution of sample companies by the year of announcement, and Panel B provides the industry distribution.

\subsection{Outside Directors}

For each director of the 409 restating companies, I collect data on age, profession, tenure, audit committee membership, other directorships, stock owned in restating company, and conflicts of interest from the proxy statement.

As discussed before, I examine only outside directors. ${ }^{18}$ Outside directors are defined as those board members who have no relationship with the company other than their role as directors. For the primary sample of 264 income-decreasing companies this classification results in 1,272 (63\% of the board) outsiders from a total of 2,020 directors. The income-increasing and technical samples have 332 (65.5\%) and 412 (67.0\%) outside directors, respectively.

DIRECTOR DEPARTURE is an indicator variable that equals 1 if the director leaves the board within three years of the restatement announcement year, and 0 otherwise. OTHER DIRECTORSHIPS measures the number of board seats held by sample directors in other public companies (not including the restating company). ${ }^{19} \mathrm{I}$ only include positions where the director is exclusively an outside monitor (such as in the restating company) and not a manager (e.g., CEO).

I collect data on other directorships in the post-restatement period as follows. For those who continue on the board, data is from the restating firm's proxy statement. For

\footnotetext{
${ }^{18}$ Recall from footnote 1 that other directors are classified as insiders and affiliated (or grey) directors. Insiders are executives of the company. Affiliated directors are those with conflicts of interests. The conflicts include consulting arrangements, family relationship, and interlocking board memberships.

${ }^{19}$ I use Compact Disclosure and SEC Edgar to check if a company is listed. Many directors serve on boards of private companies and non profits. I ignore these because this information is not uniformly disclosed (not a required disclosure) and because their importance is difficult to interpret. This convention is followed by most prior studies (e.g., Kaplan and Reihsus [1990] and Coles and Hoi, [2003].
} 
those that leave, data is no longer available in the proxy. In such cases, I collect information from the proxy of any other company where the director had served; the Standard\&Poor's Register of Corporations, Directors, and Executives; the Compact Disclosure database, and 10K Wizard. This lets me track directors even if they leave the sample company and then gain a board seat at another firm. The variable OTHER DIRECTOR LOSS is the net loss in other directorships in three years following the event year. If a director gives up one position for another, the net change is zero.

\subsection{Descriptive Statistics}

Table 4, panel A provides descriptive data on the sample companies. On average, these restatements are an economically significant event both in terms of their severity and in terms of the market's reaction to them. For the income-decreasing sample, the mean (median) cumulative magnitude of net income restated is $\$ 41.5$ million ( $\$ 5.0$ million) and the mean (median) restatement magnitude scaled by total assets (at the yearend prior to restatement announcement) is $8.3 \%$ (1.9\%). Mean (median) length of the restatement is 6.1 (4) quarters. As noted earlier, the mean (median) market reaction to the restatement announcement, measured by the CAR over a two-day window $(0,1)$, is $13.14 \%(-7.4 \%)$.

Restatements are followed by considerable legal challenges and governance changes. The SEC took enforcement action resulting in an Accounting and Auditing Enforcement Release (AAER) against 61 companies. ${ }^{20}$ Securities class action lawsuits were filed against 135 companies. CEO turnover occurred in 147 companies and CFO

\footnotetext{
${ }^{20}$ This number may be understated since the SEC typically takes a few years to complete investigations and release the AAER.
} 
changed in 191 firms, in many cases within a few days of the announcement. Auditors changed in 117 companies.

Table 4, panel A also provides descriptive statistics for income-increasing and technical restatements. Some important differences with the income-decreasing sample are seen. At the mean (median) level, income-increasing companies are significantly (at the $1 \%$ level) larger, better performers, and experience a smaller negative announcement return than income-decreasing companies. They also experience fewer lawsuits, SEC enforcement action, CEO turnover, and auditor change. This suggests that these restatements are not as serious an accounting failure as income-decreasing restatements.

Companies making technical restatements have significantly (at the $1 \%$ level) better performance and lower announcement returns than income-decreasing companies. The mean (median) announcement return of $-0.4 \%(-0.2 \%)$ is not different from zero at conventional significance levels. They do not experience any litigation or SEC action, and they have a lower rate of CEO and auditor turnover than both the earlier samples. This suggests that this sample is unlikely to suffer the penalties that are the focus of this study.

Table 4, panel B provides descriptive data on sample outside directors. For the income-decreasing sample, 712 of the 1,272 outside directors are audit committee members. The mean age and board tenure is 57.5 and 6.3 years, respectively. Outside directors do not hold large equity stakes, with a mean (median) of $1.24 \%(0.07 \%)$ of the company’s equity. The median director of the income decreasing sample owns $\$ 255,000$ worth of shares in the company. This suggests a announcement window $(0,1)$ loss of 
approximately $\$ 33,500$ and a loss of $\$ 65,000$ if held through the restatement announcement year.

\section{Restatements and Own-Board Turnover}

\subsection{Univariate Analysis}

Figure 1 plots the turnover of outside directors for three years before and after the restatement announcement year for all three samples. Restatements are followed by considerable turnover for the income-decreasing sample, with about $48.1 \%$ of the outside directors leaving within three years. Most of the turnover occurs in years 1 and 2 . Income-increasing restatements are followed by a turnover of $27.8 \%$ in a similar time frame, although the turnover is concentrated primarily in year 1. As the plot suggests, at $18.6 \%$, technical restatements do not experience a similar increase in turnover following the restatement as the other two samples. Turnover in the three years prior period averages $13.5 \%, 15.7 \%$, and $13.9 \%$ for the income-decreasing, income-increasing, and technical samples, respectively. Figure 2 plots the turnover of outside directors for the income-decreasing sample and breaks out the sample by annual (more severe) and interim (less severe) restatements. ${ }^{21}$ As expected, the plot shows that turnover is greater for annual restatements than for interim ones. In unreported statistics, I also find that in the 144 companies in the income-decreasing sample that have staggered boards, $20.1 \%$ of the outside directors leave before the end of their terms. Table 5 presents Pearson correlations for the variables for the income-decreasing restatements sample.

\subsection{Director Level Tests for Income-Decreasing Restatements Sample}

\footnotetext{
${ }^{21}$ Recall that consistent with prior literature (e.g., Myers et al. [2003]), I define as interim those restatements that corrected unaudited financials. Annual restatements are those that corrected audited financials.
} 
As discussed earlier, the primary tests examine the sample of income-decreasing restatements. Table 6 presents estimates from a logit regression of Equation (1) for this sample. $^{22}$ Model 1 presents results with the severity of restatement measured by DURATION (number of quarters restated). Model 2 measures severity by MAGNITUDE (scaled restatement value). Results show that the likelihood of director turnover increases in the severity of the restatement under both definitions of severity. The coefficient on the interaction term shows that the likelihood of audit committee members leaving is increasing in the severity of the restatement. In regressions (not reported) without the interaction term, the audit committee variable is positive though not significant at conventional levels, implying that on average audit committee members are no more likely to leave than other outside directors. This suggests that audit committee members leave only when the restatement is severe, presumably reflecting limitations in their monitoring ability. ${ }^{23}$

Among the firm level control variables, performance, CEO turnover, and board shareholding are significantly correlated with director departure. Better performance is associated with a lower probability of director departure. This is consistent with Ferris, Jagannathan, and Pritchard [2003] and Yermack [2003]. Director departure is more likely when accompanied by CEO change, consistent with Farrell and Whidbee [2000], and

\footnotetext{
${ }^{22}$ Because I use firm-level control variables in a director-level regression, the standard errors are likely to be understated because the number of independent observations is not equal to the number of directors. I correct for this with robust standard errors that take into account clustering by company. In discussing the results, I consider a 10\% (two-tailed) or better significance as a statistically significant relationship.

${ }^{23}$ In unreported results, an indicator variable for annual restatements used as the severity measure is significant both by itself and in the interaction with audit committee variable. Recall that annual restatements correct misstatements of audited financials. This can be interpreted as annual restatements being more reflective of poor monitoring in a company.
} 
Hermalin and Weisbach [1988], and is more likely with a higher level of shareholding by the board as a whole.

Among director level controls, age, tenure, other directorships are associated in a statistically significant manner. Turnover is more likely for older directors and less likely for those with greater tenure (potentially more entrenched) and for those with more other directorships. Directors who are net sellers in the company stock during the misstatement period (perhaps suggesting that they were aware of the misreporting) are more likely to turnover. All significant results are consistent across both models.

To estimate the economic magnitude, I estimate marginal effects for the explanatory variables (calculated at the mean values of the other variables). The estimates (not reported) show that a one standard deviation change in DURATION (5.0 quarters) will lead to a $5.0 \%$ increase in the likelihood of departure for non-audit committee directors and an additional 5.0\% increase for audit committee directors. A 1 standard deviation change in MAGNITUDE produces a $6.0 \%$ increase in the probability of director departure and audit committee members are $8.8 \%$ more likely to lose their positions than non-audit committee directors. The strongest effect, however, seems to be CEO change, which increases the likelihood of director change by $20 \%$ and $22 \%$ when severity is measured by DURATION and MAGNITUDE respectively. Comparison of the Pseudo $\mathrm{R}^{2}$ with and without the audit committee and severity variables shows that these variables contribute $26 \%$ ( $5 \%$ of the variation in the dependent variable in absolute terms) of the incremental explanatory power in model 1. By comparison, the firm level variables provide $51 \%$ of the incremental explanatory power. A likelihood ratio test on the null hypothesis that the audit committee, severity, and interaction terms are jointly 
equal to zero in model 1 produces a chi-square statistic of 18.02 rejecting the null at $<.001$ level of significance. The table also provides classification accuracy of the models. At 71\%, model 1 improves overall classification accuracy by about 37\% (19\% in absolute terms) compared to a naïve model which will be right $52 \%$ of the time.

Nineteen percent of directors serve on the board for periods lesser than the duration of the restatement. Many directors join the board towards the end or after the misstatement period and could therefore be part of the solution rather than the problem. Model 3 uses REST QTRS SERVED to measure the number of quarters the director served on the board of the total misstatement period. Estimates are similar to those in model 1. Results show higher departure likelihood among directors who served for a longer period and audit committee members are more likely than other directors to turn over the greater the period they have served. Model 4 repeats model 1 without CEO turnover to understand the extent to which CEO turnover dilutes the results on the restatement and audit committee variables. DURATION, AUDIT COMM X DURATION, and PERFORMANCE improve their magnitudes and significance. ${ }^{24}$

\subsection{Firm-Level Analysis for Income-Decreasing Restatements}

The analysis above in section 4.2 was at the director level. I test for robustness of these results using the company as the unit of observation. Table 7, panel A provides estimates from an ordinary least squares (OLS) regression of audit committee turnover (in percentages) at the company level on restatement severity and control variables. Models 1 and 2 present results with DURATION and MAGNITUDE as SEVERITY measures, respectively. The dependent variable is the percentage turnover in the three-

\footnotetext{
${ }^{24}$ I also repeat model 1 using CFO turnover instead of CEO turnover. The results are unchanged for the key variables. I find that the AGE variable loses its significance.
} 
year post-restatement period. Consistent with the results in table 6, audit committee turnover is increasing in restatement severity and CEO turnover, and decreasing in firm performance in both the models.

In panel $\mathrm{B}$, I use a differences approach to examine audit committee turnover relative to the non-audit committee turnover. This controls for factors that may impact the board as a whole. The dependent variable is audit committee turnover less non-audit committee turnover in the post-restatement period. The results in both models support the earlier results from table 6 that audit committee turnover increases in restatement severity relative to non-audit committee turnover.

\subsection{Income-Increasing and Technical Restatements}

Table 8 presents the estimates from a logit regression of equation (1) for incomeincreasing and technical restatements. Models 1 and 3 use DURATION while models 2 and 4 use MAGNITUDE to measure severity.

The results for the income-increasing sample are mixed. Estimates from model 1 suggest that the likelihood of departure is increasing in the severity of the restatement for audit committee members similar to that observed for income-decreasing restatements. However, duration variable is not significant by itself. Model 2 estimates for audit committee member, magnitude, and their interaction are similar to those for incomedecreasing restatements but at lower levels of significance. Likelihood of director departure is decreasing in firm performance (only model 2), director shareholding, and for directors who are CEOs. Overall, the results weakly suggest that similar to incomedecreasing restatements, the likelihood of audit committee director turnover is increasing in restatement severity relative to non-audit committee directors. 
In table 8, models 3 and 4, present results for the technical restatements sample. Consistent with expectations, the results show that there is no statistically significant relationship between director turnover and audit committee membership, restatement severity, or the interaction term. The only consistent statistically significant relationship observed is with firm performance.

\section{Loss in Other Board Positions}

\subsection{Univariate Analysis}

Figure 3 plots the number of board positions that the directors hold in other companies for the three samples. The number of outside board positions is fairly stable in the years preceding the restatement announcement. The plot shows that other directorships for the income-decreasing sample decline significantly $(\mathrm{p}<.01)$ from 1.28 to 0.97 on average, whereas the decline for the income-increasing restatements sample is much lower (and not statistically significant) from 1.35 to 1.29. Other directorships for the technical restatements sample do not change in a significant manner.

Figure 4 plots the number of board positions for directors of the incomedecreasing sample and presents the plots separately for annual and interim restatements. The decline in other directorships is greater for directors in the annual restatement sample than for those in the interim restatements sample. These plots provide some initial evidence that restatements are associated with loss in other directorships for incomedecreasing restatements. I explore this further in the next section.

\subsection{Multivariate Analysis for Income Decreasing Restatement Sample}

Table 9 presents the results of an OLS regression of equation (2). Models 1, 2, and 3 present results with DURATION, MAGNITUDE, and REST QTRS SERVED as 
the measures of severity, respectively. Model 1 results show that the coefficient of DURATION is positive and significant, suggesting that the loss in other directorships is increasing in the severity of the restatement. The coefficient on the interaction term is positive and significant. This shows that the loss in other directorships is increasing in the intensity of the restatement for audit committee members relative to those not on the audit committee. Increasing severity, therefore, has a relatively greater impact on audit committee directors presumably because they are responsible for financial reporting oversight. In regressions without the interaction term (not reported), I find a significant positive coefficient on the audit committee variable, implying that audit committee directors, on average, lose more other directorships than do non-audit committee directors. Model 2 and 3 results are similar for all the variables. In terms of economic significance, the coefficient estimates indicate that a change in restatement duration from the bottom to the top quartile (a six-quarter increase) results in an average of 0.18 (i.e., 6 $\mathrm{X}$ 0.03) board positions lost for non-audit committee directors and an average of 0.36 (i.e., 6 X $\{0.03+0.03\}$ ) board positions lost for audit committee directors. Therefore, for this increase in restatement severity, audit committee directors in the sample lose twice as many other board positions as do non-audit committee directors.

Estimated coefficients for other variables indicate that the loss in other directorships is weakly greater for older directors and less if the director is the CEO of a public company. Financial experts lose more positions than those who are not. Presumably, the reputational impact is greater when those considered experts in financial reporting are associated with financial reporting failure. Directors who leave the restating company lose more other board seats than those who remain. Finally, directors who have 
sold stock in the restating company during the misstatement period, perhaps identifying cases where they were aware of the misstatement, lose more other directorships.

\subsection{Firm Level Analysis for Income-Decreasing Restatements}

As in section 4.3, I test for robustness of these results using the company as the unit of observation. Table 10 provides estimates from an OLS regression of the loss in directorships at the company level on restatement severity and control variables. The dependent variable is the loss in directorships in the post-restatement period aggregated for the audit committee directors of the company. Models 1 and 2 presents results with DURATION and Model 2 with MAGNITUDE. Panel A results show that loss in other directorships for audit committee directors is increasing in the severity of the restatement.

In panel $\mathrm{B}$, the dependent variable is the total loss in other directorships for audit committee directors less the total loss for non-audit committee directors. The results support the earlier results in table 9 that loss in other directorships for audit committee directors increases in the severity of the restatement relative to non-audit committee directors. The results are consistent across both the models.

\subsection{Income-Increasing and Technical Restatements}

Table 11 presents results from an OLS regression of equation (2) for incomeincreasing and technical restatements. Models 1 and 2 present results for the incomeincreasing sample. Estimates from both models show no statistically significant relationship between loss in other directorships and audit committee membership, severity of the restatement, or with their interaction. This suggests that the reputational effects are not evident for income-increasing restatements. However, in regressions (not reported) without the interaction term, I find that audit committee members are more 
likely to lose their positions in both models ( $\mathrm{p}$ value $<.05$, two-tailed). The high correlation (0.78) between the variables AUDIT COMM and the interaction term, combined with a relatively smaller sample size makes it difficult to conclusively interpret the insignificant estimates.

Models 3 and 4 present results for technical restatements. The results suggest that there is no significant relationship between loss in other directorships and either audit committee membership or severity of the restatement. This is consistent with expectations because technical restatements do not indicate financial reporting failure. Among the control variables, OTHER CEO (only model 3), and OTHER DIRECTORSHIPS exhibit a significant relationship to loss in other board positions.

\section{Matched Sample Analysis and Robustness Checks}

\subsection{Constructing the Matched Sample}

The earlier samples consisted of only restatement companies and I use the severity of restatement and the number of quarters the directors served during the misstatement as a proxy for the extent of oversight failure. In order to provide a benchmark using non restating firms, I select a control sample for each company in the primary sample of income-decreasing restatements. Restatements may be a symptom of poor performance and board turnover is known to be associated with poor performance (Hermalin and Weisbach [1998]). Therefore, I identify a control firm with performance in the range of $+/-25 \%$ of the sample firm within the same four-digit Standard Industrial Classification (SIC) code (failing which I use three- and two-digit levels). Within this band I select the firm that is closest in size to the sample firm. I am able to find matches for 242 of the sample companies. For the remaining 22 companies I select the control 
firm closest in performance within the two-digit SIC code. ${ }^{25}$ I collect data on outside directors and other variables similar to that described earlier.

\subsection{Descriptive Statistics and Univariate Tests}

Table 12, panel A presents descriptive statistics for the income-decreasing and control sample companies. The two groups of firms are similar in performance and firm size indicating that the matching process has been successful. In results (not reported) I also find that they are similar on other dimensions (e.g., board size, percentage of outsiders on the board, frequency of staggered boards, CEO founder, director age, and tenure). CEO turnover is significantly greater for the income-decreasing restatements, suggesting that at a given level of performance, boards replace CEO's more often for financial reporting problems. It is not surprising that auditor turnover is also greater for the restating companies. Outside director turnover and audit committee turnover are significantly higher (at the $.1 \%$ level) for the restating companies. Finally, although the total other directorships of the two samples are similar at the starting year, the restating company directors lose twice as many other directorships as the control sample companies (significant at the $.1 \%$ level). These results suggest that directors of restating companies, particularly audit committee directors, experience turnover at a rate greater than for other companies with a similar level of performance. These directors also lose more other directorships than directors of the control group.

Because there is a difference in CEO turnover rate between the two samples, I also analyze a subsample of 51 companies where both the restating and the matched control firm experienced CEO turnover. Table 12, panel B presents univariate analysis

\footnotetext{
${ }^{25}$ Results using the 242 companies are similar to that with the total sample. Hence, I present results with the entire sample.
} 
for this subsample. The two samples are similar in performance but the median restating firm is larger than the control firm. Once again, auditor turnover is significantly greater for the restating firms. Both outside director turnover and audit committee turnover are significantly higher for the restating companies. Total loss in other directorships is also significantly greater for the restating firm directors. This provides some preliminary evidence that restating firm directors, and particularly audit committee directors, experience greater turnover and loss in other positions than a performance-matched sample, even after matching for CEO turnover.

\subsection{Director Turnover}

Table 13 provides results from firm level analysis of the restating and control samples. Because I create the control sample by matching at the firm level I do not report the results at the individual director level. ${ }^{26}$ In this section I use the regression framework to examine if audit committee directors turnover at a greater rate than non audit committee directors in the restating company compared to that in the control sample. Panel A presents results of a differences model. The dependent variable is the turnover in the audit committee less the turnover of non-audit committee directors in the restating company in three years following the restatement less the same difference in the control sample company. The explanatory variables are also expressed as differences between the restating and control firms. In model 1 the constant identifies the restatement. Model 2 and 3 use DURATION and MAGNITUDE to measure restatement severity, respectively. The control firms get a 0 value for DURATION and MAGNITUDE. The estimates from all three models show that audit committee directors of turnover at a greater rate than the

\footnotetext{
${ }^{26}$ However, I also conduct individual director level tests on a pooled sample of restatement and control sample firms similar to that in table 6 and find results consistent with the inferences drawn in this section.
} 
non-audit committee directors in the restating company compared to the control sample. Panel B presents estimates from the sub-sample where both the restating and matched firms experience CEO turnover. The inferences are consistent with that in panel A.

\subsection{Loss in Other Directorships}

The univariate results showed that directors in the restating companies lose more other directorships than those in the control sample companies. In this section I examine if audit committee directors of the restating companies lose more than non-audit committee directors compared to directors in the control group companies. Table 14 presents results from the firm level analysis. ${ }^{27}$ The dependant variable is the total loss in other directorships for audit committee directors less the loss for non audit committee directors in the restating company less the same difference for the control sample firm. As before in model 1, the constant identifies the restatement, model 2 uses DURATION and model 3 uses MAGNITUDE. Estimates from all three models are consistent with each other and suggest that the restating company audit committee directors lose more other board positions than do non-audit committee directors compared to those in the control group.

\subsection{Robustness Checks}

I conduct some robustness tests on sub samples and with alternate specifications. I examine the sub sample of companies that restated following the SEC Staff Accounting Bulletin $101 .^{28}$ I do not find evidence of increased audit committee member turnover on the own board or loss in other director positions perhaps because these restatements were

\footnotetext{
${ }^{27} \mathrm{I}$ also conduct individual director level analysis similar to that in table 9 using a pooled sample and find results consistent with the inferences in this section

${ }^{28}$ These are restatements initiated on account of the SEC clarifying its position on revenue recognition transactions. Although these may point to the use of aggressive accounting techniques, all of these were corrections to comply with new SEC rules.
} 
initiated following an SEC directive. I estimated model 1 in table 6 using turnover in year 1 instead of the three-year turnover. The results remain substantially unaltered but for the following changes. Estimates from table 6, model 1 (DURATION measure of severity) show similar magnitudes and significance for DURATION and slightly improved magnitude and similar significance for the interaction term. Tenure is no longer significant and board share improves the significance from the $10 \%$ level to the $5 \%$ level. All other variables behave similarly.

\section{Other Penalties}

\subsection{Legal Penalties}

In this section I examine whether outside directors face penalties following restatements from SEC enforcement action or securities litigation.

\subsubsection{SEC Enforcement Action}

The SEC investigated and issued an AAER against 65 of the 409 companies in the sample. Of these, 61 were against the 264 companies in the income-decreasing restatements sample and 4 were against the companies in the income-increasing restatement sample. None of the technical restatement companies faced SEC enforcement action. The SEC has not cited an outside director in any of the AAERs issued for the companies in the sample. ${ }^{29}$ The enforcement action typically is directed at managers (such as the CEO, CFO, Controller) and auditors of these companies.

\footnotetext{
${ }^{29}$ Recently, however, the SEC enforcement chief Stephen Cutler has signaled a change in attitude towards outside directors, even those not directly involved in fraud (Zwirn [2003]). In the case of Chancellor Corp, the SEC has charged an audit committee director whom the SEC alleges "recklessly ignored signs of improper accounting treatment thereby allowing management's fraud to continue" (SEC AAER No. 1764, April 24, 2003).
} 


\subsubsection{Securities Litigation}

Prior legal literature suggests that the primary reason for limited legal liability incurred by directors is the protection offered under law for good faith conduct. Courts have traditionally provided wide latitude under the business judgment rule for alleged breaches of fiduciary responsibility (Bishop [1968], Black, Cheffins, and Klausner [2003]. Black, Cheffins, and Klausner [2003] argue that actual liability for directors is almost eliminated by a combination of indemnification by their companies, D\&O (Directors and Officers) insurance, procedural rules, and settlement incentives of the plaintiffs, defendants, and insurers. However, there remains the nuisance cost of litigation, which they suggest is one factor that can motivate directors to be vigilant in monitoring managers. Black, Cheffins, and Klausner [2003] highlight the popular feeling that directorship comes with risk of legal liability and this is a leading reason for candidates turn down board responsibilities.

To examine whether outsider directors suffer costs from lawsuits filed for violation of Section 10(b) of the Securities Exchange Act of 1934 and SEC Rule 10b-5 against the restating companies, I collect data from the Stanford Securities Class Action Clearinghouse on the parties named in the securities class action lawsuit. ${ }^{30}$

Lawsuits were filed against 146 of the 409 sample companies. Of these, 135 were against the income-decreasing restatement companies and 11 were against the incomeincreasing restaters. None of the technical restatement companies were sued. Overall, 78 outside directors (of 2,016) were named as defendants in these lawsuits, of which 68 (of

\footnotetext{
${ }^{30}$ In several cases the complaint document was not available from this database. In these cases, I collected details from the Web sites of the plaintiff's law firm or from the Web sites of the major class action notice and claims administrators. This procedure enabled me to collect data for all the companies. The major class action claims administrator Web sites used for this search were www.gilardi.com and www.berdonllp.com.
} 
1,272) were from the income-decreasing sample. Of these 68 directors (from only 26 companies), 39 are audit committee members. From the income-increasing sample, only 10 directors from 5 companies were named as defendants. Therefore, even for the income-decreasing sample only about $5.5 \%$ of outside directors and audit committee members are named in these lawsuits. ${ }^{31}$ Even if the nuisance costs of being sued are high, it appears that only a small proportion of outside directors are exposed to this.

In all cases where settlement details are available, the directors (and officers) who are charged as defendants do not pay any portion of the costs themselves. The settlement amounts are typically paid by the company's D\&O insurance and by the company itself. This suggests that although litigation may be costly to the company, explicit litigation related costs borne by outside directors are not significant. However, one potentially large cost for directors not captured in this analysis is the time involved in investigation, depositions, audit committee meetings, and so forth.

\subsection{Investor Reaction}

To examine whether investors use restatements as a signal to infer poor monitoring by directors, I examine the stock price reaction for companies that share directors with restating companies. Prior research suggests that investors react to news about governance abilities of directors. Ferris, Jagannathan, and Pritchard [2003] report a significant abnormal return of $2.1 \%$ over a two day $(0,1)$ window when companies

\footnotetext{
${ }^{31}$ Content analysis of the complaints suggests that outside directors are named only when they have sold the company's stock during the misstatement period. Absent an analysis of the trading behavior of all the directors in the sample, it is not possible to conclude that stock sales during the misstatement period affect the likelihood of being sued. However, the preliminary evidence from the complaints suggests that outsider director stock sales during the misstatement period could be an important determinant of the director being named in the lawsuit.
} 
announce the appointment of a director who already has multiple directorships (a proxy for reputation). ${ }^{32}$

I conduct an event study to measure the industry adjusted CAR for companies that share directors with the income-decreasing restating sample over a two-day window $(0,1)$ surrounding the restatement announcement. The results show that companies that share directors with restating companies experience an industry adjusted CAR of $-0.24 \%$ (significant at the $10 \%$ level). The market reaction is greater for companies whose CEO serves as a director in the restating company, with an industry adjusted CAR of $-1.41 \%$ over the same window (significant at the $1 \%$ level).

These results suggest that investors revise their valuation of companies when their directors are associated with the restating companies. The impact is greater when the shared director is the CEO of their company likely because of the greater role of the CEO managing the company or because of the higher visibility for CEOs.

\section{Conclusion}

In this study I examine career and litigation consequences of accounting restatements for outside directors. Penalties for outside directors from securities litigation and enforcement action by the SEC are limited. Few outside directors are charged in securities class action lawsuits, and none has been sanctioned by the SEC. Moreover, directors do not pay any portion of the settlement because they are protected by insurance and by the company from personal financial loss.

However, directors of companies that make severe income-decreasing restatements face a high risk of turnover on the restating company board. Furthermore,

\footnotetext{
${ }^{32}$ Other studies that present event study evidence in a similar context include Shivdasani and Yermack [1999] and Perry and Peyer [2003].
} 
for severe restatements the likelihood of departure is higher for audit committee members, who have direct responsibility for overseeing the financial reporting process, than for non-audit committee directors. Outside directors also lose positions on other boards following a restatement. This loss increases in restatement severity, particularly for audit committee members.

I also find weak evidence that directors of income-increasing restatement companies suffer similar penalties, though consistent inference is difficult. As expected, I find no evidence of any penalty for directors or audit committee members in the technical restatements sample. The matched-sample analysis complements the within sample tests and provides further evidence that the labor market consequences of restatements for audit committee directors is greater than for non-audit committee directors.

I eliminate from the sample all firms that have delisted or merged following the restatement. In a sense these are the worst performers and penalties for directors should be the most severe in these firms. All the directors of the delisted firms are no longer directors of the listed company. The same would be the case for merged companies because in directors of the acquired entity do not normally join the acquiring board (Harford [2003]). Based on the results in the other samples, we may expect that these directors would also suffer a loss in other directorships.

It is an open question whether a restatement signifies success or failure on the part of the audit committee, as audit committees oversee the process under which accounting irregularities are both committed and detected. Success implies rewards and failure implies penalties. Although both these effects could be present, the results suggest that the net effect of failure dominates. 
These results are consistent with directors, particularly audit committee members, bearing a reputational penalty for weak board and audit committee oversight. However, it is possible instead that the results reflect directors voluntarily opting out of boards. Directors may leave their positions if the restatement causes them to revalue the cost of the effort required as greater than the benefits from board membership. Because companies do not identify the reasons for director departure, it is difficult to judge whether turnover is voluntary or forced. Either way, the restatement can be considered as negatively affecting board members because it reduces their opportunities to serve, and benefit from the reputation and prestige that board membership offers.

In conclusion, although the evidence can be interpreted as ex-post settling up in the labor market for directors, it is unclear whether this penalty is fully appreciated exante by directors. Furthermore, it is an open question whether such costs alone provide adequate motivation for outside directors, particularly in light of the regulatory intent to assign a greater role for audit committees to improve the quality of financial reporting. 


\section{References}

Agarwal, A., and S. Chadha. "Corporate Governance and Accounting Scandals.” Journal of Law and Economics October (2005): Forthcoming.

Agarwal, A.; J.F. Jaffe; and J.M. Karpoff. "Management Turnover and Governance Changes Following the Revelation of Fraud.” Journal of Law and Economics 17 (1999): 309-42.

Agarwal, A., and C.R. Knoeber. "Do Some Ouside Directors Play a Political Role?” Jounral of Law and Econmics 14 (2001): 179-198.

Beasley, M.S. “An Empirical Analysis of the Relation between the Board of Director Composition and Financial Statement Fraud.” The Accounting Review 71 (1996): 433-65.

Bebchuk, L., and A. Cohen. "The Costs of Entrenched Boards.” Working Paper, Harvard Law School, 2004.

Bebchuk, L.; J. Coates IV; and G. Subramanian. “The Powerful Antitakeover Force of Staggered Boards: Theory, Evidence and Policy.” Stanford Law Review 54 (2002): 887-951.

Beneish, M.D. "Incentives and Penalties Related to Earnings Overstatements that Violate GAAP.” The Accounting Review 74 (1999): 425-57.

Bishop, J. "Sitting Ducks and Decoy Ducks: New Trends in the Indemnification of Corporate Directors and Officers.” Yale Law Journal 77 (1968): 1078-1103.

Black, B.; B. Cheffins; and M. Klausner. “Outside Director Liability.” Working Paper, Stanford Law School, 2003.

Booth, J.R., and D.N. Deli. "Factors Affecting the Number of Outside Directorships Held by CEOs.” Journal of Financial Economics 40 (1996): 81-104.

Bowen, R.; S. Rajgopal; and M. Venkatachalam. "Accounting Discretion, Corporate Governance, and Firm Performance.” Working paper, Fuqua School of Business, Duke University, 2003.

Brickley, J.A.; J.L. Coles; and J.S. Linck. "What Happens to CEOs after They Retire? New Evidence on Career Concerns, Horizon Problems, and CEO Incentives." Journal of Financial Economics 52 (1999): 341-77.

Brickley, J.A.; J.L. Coles; and R. Terry. "The Board of Directors and Enactment of Poison Pills.” Journal of Financial Economics 35 (1994): 371-90. 
Bushman, R.; Q. Chen; E. Engel; and A. Smith. "The Sensitivity of Corporate Governance Systems to the Timeliness of Accounting Earnings.” Working paper, University of Chicago, 2000.

Callen, J.L.; J. Linat; and D. Segal. "Accounting Restatements: Are They Always Bad News?” Working Paper, Rotman School of Management, University of Toronto, 2002.

Carcello, J.V., and T.L. Neal. "Audit Committee Composition and Auditor Reporting.” The Accounting Review 75 (2000): 453-67.

Coles, J.L., and C.K. Hoi. "New Evidence on the Market for Directors: Board Membership and Pennsylvania Senate Bill1310.” Journal of Finance 58 (2003): 197-230.

Davis, G.F., and H. Greve. "Corporate Elite Networks and Governance Changes in the 1980’s.” American Journal of Sociology 103 (1997): 1-37.

Davis, G.; M. Yoo; and W.E. Baker. "The Small World of American Corporate Elite, 1982-2001.” Strategic Organization 1 (2003): 301-26.

Dechow, P.M.; R.G. Sloan; and A. Sweeny. "Causes and Consequences of Earnings Manipulation: An Analysis of Firms Subject to Enforcement Actions by the SEC.” Contemporary Accounting Research 13 (1996): 1-36.

Desai, H.; C.E. Hogan; and M.S. Wilkins. "The Repuational Penalty for Aggressive Accounting: Earnings Restatements and Management Turnover.” Working Paper, Southern Methodist University, 2004.

Fama, E. “Agency Problems and the Theory of the firm.” Journal of Political Economy. 88 (1980), 288-307.

Fama, E.F., and M.C. Jensen. "Separation of Ownership and Control." Journal of Law and Economics 26 (1983), 301-325.

Farber, D. “Restoring Trust After Fraud: Does Corporate Governance Matter?” Working Paper, Michigan State University, 2004.

Farrell, K.A., and D.A. Whidbee. "The Consequences of Forced CEO Succession for Outside Directors.” Journal of Business 73 (2000), 597-628.

Felton, R.F.; K. Berryman; and T. Stephenson. “A New Era in Corporate Governance.” McKinsey Quarterly 2 (2004): 28. 
Ferris, S.P.; M. Jagannathan; and A.C. Pritchard. "Too Busy to Mind the Business? Monitoring by Directors with Multiple Board Appointments.” Journal of Finance 58 (2003): 1087-1112.

General Accounting Office (GAO). "Financial Statement Restatements: Trends, Market Impacts, Regulatory Responses, and Remaining Challenges.” General Accounting Office, GAO-03-138, 2002.

Gilson, S.C. "Bankruptcy, Boards, Banks, and Bondholders: Evidence on Changes in Corporate Ownership and Control When Firms Default.” Journal of Financial Economics 27 (1990): 355-88.

Harford, J. "Takeover Bids and Target Directors' Incentives: The Impact of a Bid on Directors Wealth and Board Seats.” Journal of Financial Economics 69 (2003): 51-84.

Hermalin, B.E., and M.S. Weisbach. "The Determinants of Board Composition.” RAND Journal of Economics 19 (1988): 589-606.

Hooghiemstra R., and J. van Manen. "The Independence Paradox: (Im)possibilities Facing Non-Executive Directors in The Netherlands”. Corporate Governance 12 (2004): 314-324.

Hribar, P., and N.T. Jenkins. "The Effect of Accounting Restatements on Earnings Revisions and Estimated Cost of Capital.” Review of Accounting Studies 9 (2004): 337-356.

Jensen, Michael C. "The Modern Industrial Revolution, Exit, and the Failure of Internal Control Systems.” The Journal of Finance (July 1993): 831-880.

Kaplan, S.N., and D. Reishus. "Outside Directorships and Corporate Performance." Journal of Financial Economics 27 (1990): 389-410.

Khurana, R. Searching for a Corporate Savior. Princeton, NJ: Princeton University Press, 2002.

Kinney, W.R., Jr., and L.S. McDaniel. "Characteristics of Firms Correcting Previously Reported Quarterly Earnings.” Journal of Accounting and Economics 11 (1989): 71-93.

Kinney, W. R., Jr.; Z.-V. Palmrose; and S. Scholz. “Auditor Independence and NonAudit Services: What do Restatements Suggest?” Working Paper, University of Texas-Austin, 2003.

Klein, A. "Audit Committee, Board of Director Characteristics, and Earnings Management.” Journal of Accounting and Economics 33 (2002): 375-400. 
Larcker, D.F., and S. Richardson. "Corporate Governance, Fees for Non-audit Services and Accrual Choices.” Working paper, University of Pennsylvania, 2003.

Larcker, D.F.; S. Richardson; and I. Tuna. "Does Corporate Governance Really Matter?” Working Paper. The Wharton School, University of Pennsylvania, 2004.

Livingston, J.G. “ Management Borne Costs of Fraudulent and Misleading Reporting.” Unpublished Dissertation. University of Rochester, 1997.

Lorsch, J.L., and E.M. MacIver. Pawns or Potentates? The Reality of America's Corporate Boards. Boston, MA: Harvard Business School Press, 1989.

Mace, M. Directors: Myth and Reality. Boston, MA: Harvard Business School Press, 1986.

McDaniel, L.; R.D. Martin.; and L.A. Maines. "Evaluating Financial Reporting Quality.” The Accounting Review 77 (Supplement 2002): 139-67.

Myers, J.N.; L.A. Myers; Z.-V. Palmrose; and S. Scholz. "Mandatory Auditor Rotation: Evidence from Restatements.” Working Paper, University of Illinois at UrbanaChampaign, 2003.

Palmrose, Z.-V.; V.J. Richardson; and S.W. Scholz. "Determinants of Markets Reactions to Restatement Announcements." Journal of Accounting and Economics 37 (2004): 58-89.

Palmrose, Z.-V., and S.W. Scholz. "The Circumstances and Legal Consequences of NonGAAP Reporting: Evidence from Restatements.” Contemporary Accounting Research 21 (2004): 139-190.

Perry, T., and U. Peyer. "Board seat accumulation by executives: a shareholder's perspective.” Working paper, Arizona State University, 2003.

Raghunandan, K.; W.J. Read; and J.S. Whinesant. "Initial Evidence on the Association between Nonaudit Fees and Restated Financial Statements." Accounting Horizons 17 (2003): 223-34.

Richardson, S.; I. Tuna; and M. Wu. "Capital Market Pressures and Earnings Management: The Case of Earnings Restatements." Working Paper, University of Pennsylvania, 2003.

Shivdasani, A., and D. Yermack. "CEO Involvement in the Selection of New Board Members: An Empirical Analysis.” The Journal of Finance 54 (1999): 1829-53. 
Skinner, D.J. "Earnings Disclosures and Stockholder Lawsuits.” Journal of Accounting and Economics 23 (1999): 249-82.

U.S. Securities and Exchange Commission (SEC). "Standards Relating to Listed Company Audit Committees.” Release Nos 33-8220; 34-47654, IC-26001; File No. S7-02-03. U.S. Securities and Exchange Commission, 2003.

Wu, M. “Restatements.” Unpublished Dissertation, New York University, 2002.

Yermack, D. "Higher Market Valuation of Companies with a Small Board of Directors", Journal of Financial Economics 40 (1996): 185-211.

Yermack, D. "Remuneration: Retention and Reputation Incentives for Outside Directors.” Working Paper, New York University, 2003.

Zwirn, E. “Warning Shot from SEC’s Cutler.” August 22, $2003<$ <ttp://www.CFO.com>. 


\section{Table 1 \\ Variable Definitions}

\begin{tabular}{|c|c|}
\hline Variable Name & Definitions \\
\hline DIRECTOR DEPARTURE & $\begin{array}{l}\text { Indicator variable that equals } 1 \text { if the director leaves the board within three years } \\
\text { of the restatement, and } 0 \text { otherwise. }\end{array}$ \\
\hline OTHER DIRECTORSHIPS & Number of positions held as an outside director in other public companies. \\
\hline OTHER DIRECTOR LOSS & $\begin{array}{l}\text { Net loss in the number of other directorships held by the director in the three } \\
\text { years following the restatement announcement. }\end{array}$ \\
\hline AUDIT COMM & $\begin{array}{l}\text { Indicator variable that equals } 1 \text { if the director is member of the firms audit } \\
\text { committee and } 0 \text { otherwise. }\end{array}$ \\
\hline SEVERITY & $\begin{array}{l}\text { Severity of the restatement measured by DURATION and MAGNITUDE defined } \\
\text { below. }\end{array}$ \\
\hline DURATION & Number of quarters for which net income is restated. \\
\hline MAGNITUDE & $\begin{array}{l}\text { Cumulative amount of net income restated scaled by total assets at the year-end } \\
\text { before the restatement announcement. }\end{array}$ \\
\hline REST QTRS SERVED & $\begin{array}{l}\text { Measures the actual number of quarter the directors served during the } \\
\text { misstatement period. }\end{array}$ \\
\hline PERFORMANCE & $\begin{array}{l}\text { Firms' stock return in the same three year window as used to measure } \\
\text { DEPARTURE and OTHER DIRECTOR LOSS less CRSP value-weighted index, } \\
\text { with both returns compounded continuously before differencing. }\end{array}$ \\
\hline SIZE & Total assets in billions at the year-end prior to the restatement announcement. \\
\hline CEO TURNOVER & $\begin{array}{l}\text { Indicator variable that equals } 1 \text { if the CEO of the restating company is changed } \\
\text { within three years of the restatement and } 0 \text { otherwise. }\end{array}$ \\
\hline BOARD SIZE & Number of directors on the board of the restating company. \\
\hline BOARD SHARE & $\begin{array}{l}\text { Board shareholding in the restating company measured by the percentage of the } \\
\text { firm's equity held by the board as a whole. }\end{array}$ \\
\hline OUTSIDERS & Ratio of outside directors to the total board size \\
\hline CEO FOUNDER & $\begin{array}{l}\text { Indicator variable that takes the value } 1 \text { if the CEO is the founder of the company } \\
\text { or belongs to the founding family. }\end{array}$ \\
\hline$A G E$ & Age of the director at the restatement year. \\
\hline TENURE & $\begin{array}{l}\text { Number of years the director has spent on the board of the restating company at } \\
\text { the time of the restatement announcement. }\end{array}$ \\
\hline DIRECTOR SHARE & $\begin{array}{l}\text { Directors shareholding in the restating company measured by the percentage of } \\
\text { shares of the total equity of the company held by the director. }\end{array}$ \\
\hline OTHER CEO & $\begin{array}{l}\text { Indicator variable that equals } 1 \text { if director is CEO of another public company and } \\
0 \text { otherwise. }\end{array}$ \\
\hline FIN EXPERT & $\begin{array}{l}\text { Indicator variable identifying whether the director is a financial expert as defined } \\
\text { under SEC "Standards Relating to Listed Company Audit Committee" (SEC } \\
\text { [2003]); it equals1 if financial expert, 0 otherwise. }\end{array}$ \\
\hline DIR AFTER CEO & $\begin{array}{l}\text { Indicator variable that equals } 1 \text { if the director joined the board after the CEO and } \\
0 \text { otherwise. }\end{array}$ \\
\hline DIR SELLER & $\begin{array}{l}\text { Indicator variable that equals } 1 \text { if director is a net seller in the company stock } \\
\text { during the misstatement period, and } 0 \text { otherwise. }\end{array}$ \\
\hline
\end{tabular}




\section{Table 2}

\section{Sample Selection}

Total number of restatements announced from 1997 to 2000

Less: Companies that did not eventually restate

Less: Repeat restatements by the same company:

Less: Foreign companies

Less: Companies not on Compustat or CRSP

Less: Companies that stop proxy disclosures because of delisting or mergers

Companies with required information available - final sample

409

Restatements for “technical” reasons

not amounting to misstatements

Income-increasing restatements

Income-decreasing restatements (primary sample) 
Table 3

Descriptive Statistics for Distribution of Sample Companies by Year and Industry

Panel A reports the distribution of sample companies by year of restatement announcement as reported in General Accounting Office [2002]. The columns titled "Income-Decreasing" "Income-Increasing" and "Technical" refer to companies in the income-decreasing, income-increasing, and technical restatement samples, respectively. Industries are defined by the following SIC codes: Agriculture, mining and construction = 0-1999; Manufacturing = 2000-3999 (except codes assigned to Technology); Technology = $3570-3579$ plus 7370-7379; Transportation $=4000-4799$; Communications $=4800-4899$; Utilities $=$ 4900-4999; Wholesale/retail $=$ 5000-5999; Financial Services $=6000-6999$; Services $=7000-8999$ (except codes assigned to Technology). Industry classification is taken from Palmrose and Scholz [2004].

\begin{tabular}{c|cl|cl|cl|cl}
\hline & \multicolumn{2}{|c|}{ Income Decreasing } & Income Increasing & \multicolumn{2}{|c|}{ Technical } & \multicolumn{2}{|c}{ Total } \\
\hline Year & $\mathrm{N}$ & $\%$ & $\mathrm{~N}$ & $\%$ & $\mathrm{~N}$ & $\%$ & $\mathrm{~N}$ & $\%$ \\
\hline 1997 & 35 & $13.3 \%$ & 8 & $11.6 \%$ & 10 & $13.2 \%$ & 53 & $12.9 \%$ \\
1998 & 43 & $16.3 \%$ & 8 & $11.6 \%$ & 7 & $9.2 \%$ & 58 & $14.2 \%$ \\
1999 & 50 & $18.9 \%$ & 29 & $42.0 \%$ & 11 & $14.4 \%$ & 90 & $22.0 \%$ \\
2000 & 73 & $27.7 \%$ & 6 & $8.8 \%$ & 24 & $31.6 \%$ & 103 & $25.2 \%$ \\
2001 & 63 & $23.8 \%$ & 18 & $26.0 \%$ & 24 & $31.6 \%$ & 105 & $25.7 \%$ \\
Total & 264 & $100 \%$ & 69 & $100 \%$ & 76 & $100 \%$ & 409 & $100 \%$ \\
\hline
\end{tabular}

Panel B: Industry Distribution of Sample Companies

\begin{tabular}{|c|c|c|c|c|c|c|c|c|}
\hline $\begin{array}{l}\text { Agriculture, } \\
\text { mining, } \\
\text { construction }\end{array}$ & 6 & $23 \% 1$ & 2 & 290 & 0 & ) 0 & 8 & $20 \%$ \\
\hline Communication & 4 & $1.5 \%$ & 0 & $0.0 \%$ & 1 & $1.3 \%$ & 4 & $1.0 \%$ \\
\hline $\begin{array}{l}\text { Financial } \\
\text { services }\end{array}$ & 37 & $14.0 \%$ & 7 & $10.1 \%$ & 11 & $14.5 \%$ & 55 & $13.4 \%$ \\
\hline Manufacturing & 91 & $34.5 \%$ & 26 & $37.7 \%$ & 34 & $44.7 \%$ & 151 & $36.9 \%$ \\
\hline Services & 32 & $12.1 \%$ & 6 & $8.7 \%$ & 4 & $5.3 \%$ & 42 & $10.3 \%$ \\
\hline Technology & 59 & $22.3 \%$ & 19 & $27.5 \%$ & 8 & $10.5 \%$ & 86 & $21.0 \%$ \\
\hline Transportation & 4 & $1.5 \%$ & 0 & $0.0 \%$ & 0 & $0.0 \%$ & 4 & $1.0 \%$ \\
\hline Utilities & 7 & $2.7 \%$ & 0 & $0.0 \%$ & 3 & $3.9 \%$ & 11 & $2.7 \%$ \\
\hline Wholesale/retail & 23 & $8.7 \%$ & 9 & $13.0 \%$ & 15 & $19.7 \%$ & 47 & $11.5 \%$ \\
\hline Other & 1 & $0.4 \%$ & 0 & $0.0 \%$ & 0 & $0.0 \%$ & 1 & $0.2 \%$ \\
\hline Total & 264 & $100 \%$ & 69 & $100 \%$ & 76 & $100 \%$ & 409 & $100 \%$ \\
\hline
\end{tabular}




\section{Table 4}

Descriptive Statistics for Sample companies and Outside Directors of Sample Companies

Please refer to table 1 for variable definitions. The column titled "Income-Decreasing”, "IncomeIncreasing", and "Technical” refer to companies in the Income-decreasing, income-increasing, and technical restatement samples, respectively.

\begin{tabular}{|c|c|c|c|c|c|c|}
\hline \multirow[b]{2}{*}{ Variable } & \multicolumn{2}{|c|}{ Income Decreasing } & \multicolumn{2}{|c|}{ Income Increasing } & \multicolumn{2}{|c|}{ Technical } \\
\hline & Mean & (Median) & Mean & (Median) & Mean & (Median) \\
\hline \multicolumn{7}{|c|}{ Panel A: Descriptive statistics for restating companies. } \\
\hline \multicolumn{7}{|l|}{ RESTATEMENT AMOUNT } \\
\hline (\$millions) & 41.5 & $(5.0)$ & 28.30 & $(12.0)$ & 22.4 & (3.2) \\
\hline MAGNITUDE (scaled) & $8.3 \%$ & $(1.9 \%)$ & $7.1 \%$ & $(4.5 \%)^{*}$ & $6.5 \%$ & $(0.8 \%)^{\mathrm{a}}$ \\
\hline DURATION (no. of Quarters) & 6.1 & (4) & 5.5 & $(4)$ & $5.1^{\mathrm{a}}$ & $(4)$ \\
\hline ANNOUNCEMENT RETURN $(0,1)$ & $-13.14 \%{ }^{* \star \star}$ & $(-7.4 \%)^{\star \star \star}$ & $-4.7 \%^{a_{1 \star \star \star}}$ & $(-4.6 \%)^{a_{1, \star \star *}}$ & $-0.4 \%^{a}$ & $(-0.2 \%)^{\mathrm{a}}$ \\
\hline PERFORMANCE & $-11.6 \%$ & $(-24.2 \%)$ & $-2.28 \%^{\mathrm{a}}$ & $(-5.8 \%)^{a}$ & $17.5 \%^{\mathrm{a}}$ & $(4.3 \%)^{a}$ \\
\hline SIZE (total assets \$ millions) & 2460 & $(224)$ & $4475^{\mathrm{a}}$ & $(462)^{a}$ & 1913 & $(443)^{a}$ \\
\hline BOARD SIZE & 7.6 & (7) & 7.4 & $(7)$ & 8.1 & $(7)$ \\
\hline BOARD SHARE & $21.1 \%$ & $(14.8 \%)$ & $15.9 \%^{\mathrm{a}}$ & $(7.9 \%)$ & $14.8 \%^{\mathrm{a}}$ & $(11.0 \%)$ \\
\hline OUTSIDERS & $63.0 \%$ & $(67.0 \%)$ & $65.5 \%^{\mathrm{a}}$ & $(66.6 \%)^{a}$ & $67.0 \%^{\mathrm{a}}$ & $(66.7 \%)^{a}$ \\
\hline OUTSIDE DIRECTOR TURNOVER & $48.1 \%$ & & $27.8 \%^{\mathrm{a}}$ & & $18.6 \%^{\mathrm{a}}$ & \\
\hline NUMBER OF COMPANIES SUED & 135 & & 11 & & 0 & \\
\hline SEC AAER ACTIONS & 61 & & 4 & & 0 & \\
\hline CEO TURNOVER & 147 & & 22 & & 8 & \\
\hline AUDITOR CHANGE & 117 & & 20 & & 11 & \\
\hline$N$ & 264 & & 69 & & 76 & \\
\hline
\end{tabular}

\section{Panel B: Descriptive statistics for outside directors}

\begin{tabular}{l|ll|ll|ll}
\hline AGE & 57.5 & $(58)$ & 57.2 & $(57)$ & 56.6 & $(56)$ \\
TENURE & 6.3 & $(5.0)$ & 5.8 & $(4.0)$ & 7.1 & $(6.0)$ \\
DIRECTOR SHARE & 1.24 & $(0.07)$ & 0.68 & $(0.02)$ & 0.97 & $(0.04)$ \\
OTHER DIRECTORSHIPS & 1.28 & $(1.0)$ & 1.35 & $(1.0)$ & 1.24 & $(1.0)$ \\
AUDIT COMM DIRECTORS & 712 & & 175 & & 226 & \\
$N$ & 1272 & & 332 & & 412 & \\
\hline
\end{tabular}

a Indicates that the mean (median) is significantly different from the mean (median) of the incomedecreasing sample at the $5 \%$ level or less (two-sided) based on a t-test (Wilcoxon test).

*** implies significantly different from zero at the $1 \%$ level (two-tailed). 


\section{Figure 1 \\ Outside Director Turnover}

Outside Director Turnover

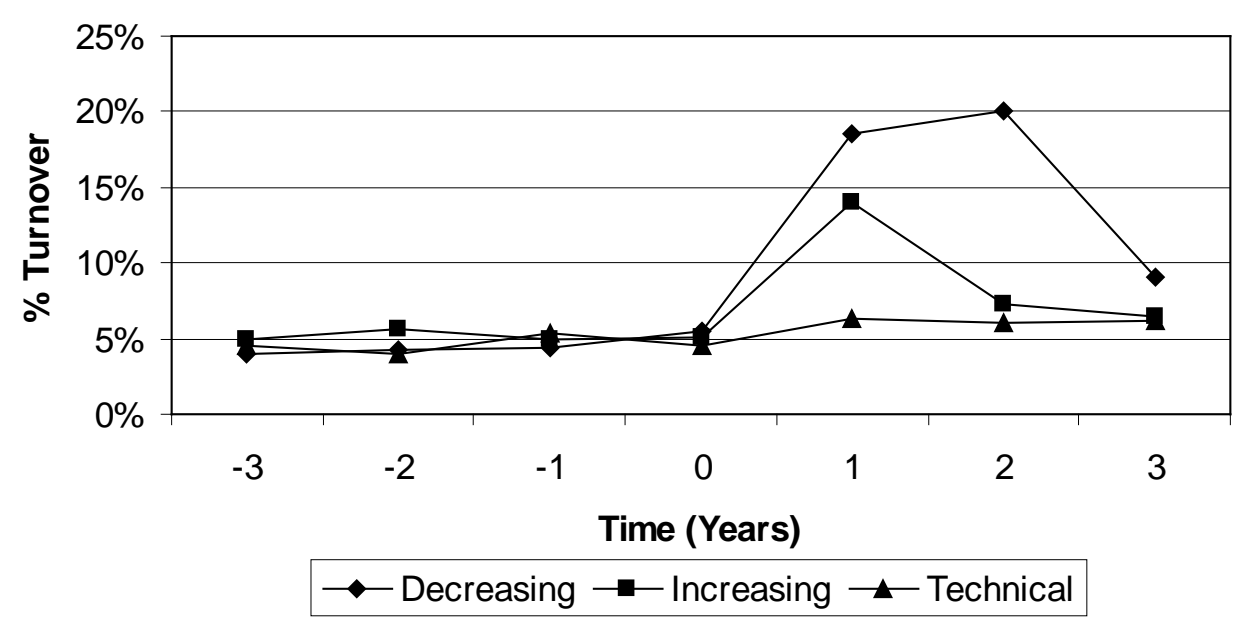

FIG. 1- Outside director turnover in restating companies. The plots below show the average outside director turnover for companies in the income-decreasing, income-increasing, and technical restatements samples. Year 0 is the year of the restatement announcement. The legend below identifies the plots. "Decreasing" refers to the income-decreasing restatements sample, "Increasing" refers to the incomeincreasing restatements sample, and “Technical” refers to the technical restatements sample.

Figure 2

\section{Outside Director Turnover}

\section{Outside Director Turnover}

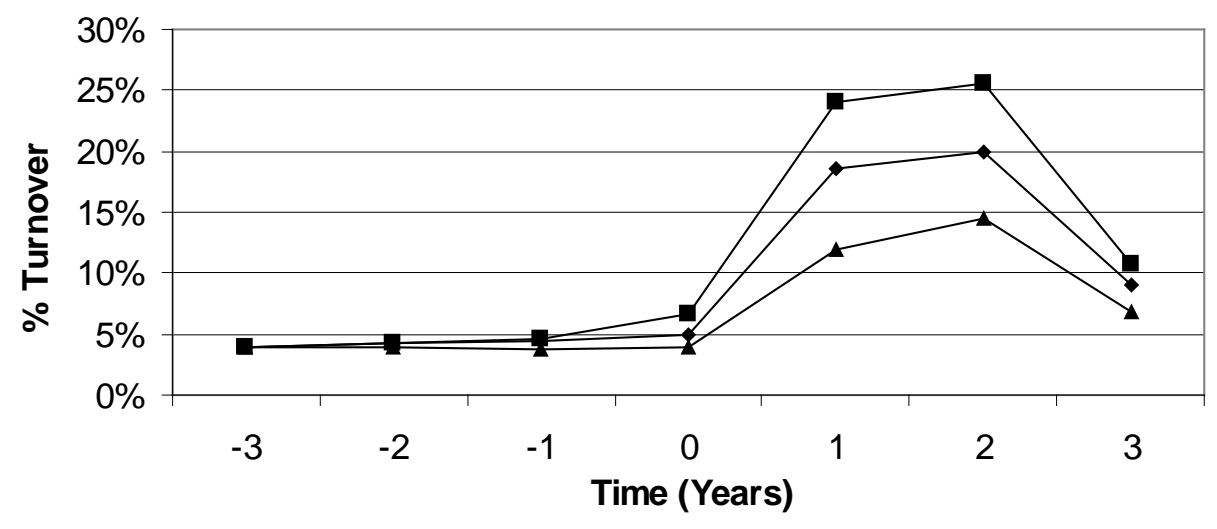

$$
\neg \text { Interim restatement } \rightarrow \text { Annual restatement } \multimap-\text { Total sample }
$$

FIG. 2- Outside director turnover in the income-decreasing restatements sample. The plots below show the average outside director turnover for companies in income-decreasing sample. Year 0 is the year of the restatement announcement. The legend below identifies the plots. "Interim restatements" refers to the sample of companies that issue quarterly restatements, "Annual restatements" refer to companies that restate audited annual financials, and "Total sample" refers to the entire sample of income decreasing restatements. 
Table 5

Univariate Correlations

The table presents correlations matrix for the primary sample of income-decreasing restatements. Please refer to table 1 for variable definitions. ** indicates significance at the $5 \%$ level (two-tailed).

\begin{tabular}{|c|c|c|c|c|c|c|c|c|c|c|c|c|c|c|c|c|c|c|}
\hline & 1. & 2. & 3. & 4. & 5. & 6. & 7. & 8. & 9. & 10. & 11. & 12. & 13. & 14. & 15. & 16. & 17. & 18. \\
\hline \multicolumn{19}{|l|}{$\begin{array}{l}\text { 1. DIRECTOR } \\
\text { DEPARTURE }\end{array}$} \\
\hline $\begin{array}{l}\text { 2. OTHER } \\
\text { DIRECTOR LOSS }\end{array}$ & $0.16^{\star \star}$ & & & & & & & & & & & & & & & & & \\
\hline 3. AUDIT COMM & -0.01 & $0.13^{\star \star}$ & & & & & & & & & & & & & & & & \\
\hline 4. DURATION & $0.23^{\star \star}$ & $0.21^{\star \star}$ & -0.01 & & & & & & & & & & & & & & & \\
\hline 5. MAGNITUDE & $0.18^{\star \star}$ & $0.23^{\star \star}$ & -0.02 & $0.42^{\star *}$ & & & & & & & & & & & & & & \\
\hline 6. PERFORMANCE & $-0.15^{\star \star}$ & $-0.04^{\star *}$ & -0.03 & $-0.11^{\star \star}$ & $-0.08^{\star \star}$ & & & & & & & & & & & & & \\
\hline 7. SIZE & -0.03 & $0.09^{\star \star}$ & $-0.10^{\star *}$ & $0.10^{\star \star}$ & $0.24^{\star *}$ & 0.05 & & & & & & & & & & & & \\
\hline 8. CEO TURNOVER & $0.23^{\star \star}$ & $0.15^{\star \star}$ & -0.02 & $0.15^{\star \star}$ & -0.01 & $-0.22^{\star \star}$ & -0.00 & & & & & & & & & & & \\
\hline 9. BOARD SIZE & -0.01 & $0.09^{\star \star}$ & $-0.20^{\star \star}$ & $0.16^{\star \star}$ & 0.04 & -0.02 & $0.45^{\star \star}$ & 0.00 & & & & & & & & & & \\
\hline 10. BOARD SHARE & $0.04^{\star \star}$ & -0.04 & 0.05 & -0.06 & -0.03 & $-0.11^{\star *}$ & $-0.29^{\star \star}$ & $-0.13^{\star *}$ & $-0.30^{\star \star}$ & & & & & & & & & \\
\hline 11. OUTSIDERS & -0.03 & $-0.06^{\star \star}$ & -0.02 & 0.01 & $-0.13^{\star \star}$ & 0.03 & $0.13^{\star \star}$ & 0.01 & 0.03 & $-0.15^{\star \star}$ & & & & & & & & \\
\hline 12. CEO FOUNDER & 0.01 & -0.05 & 0.05 & -0.03 & -0.05 & -0.01 & 0.10 & -0.04 & $-0.25^{\star \star}$ & $0.20^{\star *}$ & $-0.21^{\star *}$ & & & & & & & \\
\hline 13. AGE & 0.03 & $0.13^{\star \star}$ & $0.07^{\star \star}$ & 0.04 & $0.11^{\star \star}$ & 0.05 & $0.15^{\star \star}$ & -0.07 & $0.11^{\star \star}$ & $-0.06^{\star \star}$ & $0.11^{\star \star}$ & $-0.17^{\star \star}$ & & & & & & \\
\hline $\begin{array}{l}\text { 14.TENURE } \\
\text { 15. DIRECTOR }\end{array}$ & $-0.06^{\star *}$ & $0.06^{\star \star}$ & 0.03 & 0.04 & 0.04 & 0.04 & $0.10^{\star \star}$ & $-0.17^{\star \star}$ & $0.10^{\star \star}$ & $-0.10^{\star \star}$ & 0.02 & -0.10 & $0.38^{\star \star}$ & & & & & \\
\hline SHARE & 0.03 & 0.04 & -0.01 & -0.04 & -0.01 & -0.07 & $-0.10^{\star \star}$ & $0.08^{\star \star}$ & $-0.10^{\star \star}$ & $0.30^{\star \star}$ & -0.00 & $-0.04^{\star *}$ & $-0.06^{\star *}$ & 0.00 & & & & \\
\hline 16. OTHER CEO & -0.01 & $-0.09 * *$ & 0.00 & 0.07 & 0.01 & 0.02 & $0.10^{\star \star}$ & 0.00 & $0.09 * \star$ & -0.04 & 0.05 & $-0.02^{\star *}$ & -0.02 & $-0.07^{\star \star}$ & $-0.10^{\star *}$ & & & \\
\hline $\begin{array}{l}\text { 17. OTHER } \\
\text { DIRECTORSHIPS }\end{array}$ & $-0.01^{\star \star}$ & $0.62^{\star \star}$ & $0.08^{\star \star}$ & $0.12^{\star *}$ & $0.17^{\star \star}$ & $-0.08^{\star *}$ & $0.25^{\star \star}$ & $0.15^{\star \star}$ & $0.15^{\star \star}$ & $-0.11^{\star \star}$ & 0.06 & $-0.15^{\star \star}$ & $0.18^{\star \star}$ & 0.05 & $0.07^{\star \star}$ & -0.01 & & \\
\hline 18. FIN EXPERT & 0.00 & $0.10^{\star \star}$ & $0.34^{\star \star}$ & $0.07^{\star \star}$ & 0.01 & -0.03 & 0.01 & 0.01 & 0.00 & -0.02 & $-0.08^{\star \star}$ & -0.00 & -0.06 & -0.05 & 0.00 & $0.21^{\star \star}$ & $0.08^{\star \star}$ & \\
\hline 19. DIR AFTER CEO & 0.03 & -0.05 & -0.05 & 0.03 & -0.05 & -0.10 & -0.05 & $0.03^{\star \star}$ & $-0.06^{\star \star}$ & $0.27^{\star \star}$ & $-0.03^{\star *}$ & 0.14 & $-0.19^{\star *}$ & $-0.33^{\star \star}$ & -0.04 & 0.03 & -0.10 & 0.00 \\
\hline 20. NET SELLER & $0.04^{\star \star}$ & $0.12^{\star \star}$ & $0.04^{\star \star}$ & $0.06^{\star \star}$ & $0.08^{\star *}$ & 0.11 & -0.00 & $0.07^{\star \star}$ & -0.01 & -0.00 & $0.05^{\star \star}$ & 0.00 & 0.02 & $0.16^{\star *}$ & 0.03 & -0.01 & 0.00 & 0.03 \\
\hline
\end{tabular}




\section{Table 6 \\ Loss of Board Position in Restating Company Income-Decreasing Restatements}

The table presents estimates from a logit regression of the probability of outside director departure from the board on director level and firm level variables. $\mathrm{Y}=1$ if the director leaves the board. The t-statistics (in parentheses) are robust to heteroskedasticity and are adjusted for clustering by company. Models 1 and 4 measures SEVERITY by DURATION, model 2 measures SEVERITY by MAGNITUDE, and model 3 by REST QTRS SERVED. Please refer to table 1 for variable definitions. $\mathrm{N}=1,272$ for all the models. *,**, *** indicate significance at $10 \%, 5 \%$ and $1 \%$ levels (two-tailed). $\operatorname{Pr}(\mathrm{Y}=1)=\mathrm{F}\left(\alpha_{0}+\alpha_{1}\right.$ AUDIT COMM $+\alpha_{2}$ SEVERITY $+\alpha_{3}$ AUDIT COMM X SEVERITY $+\alpha_{4}$ PERFORMANCE $+\alpha_{5}$ SIZE + $\alpha_{6}$ CEO TURNOVER $+\alpha_{7}$ BOARD SIZE $+\alpha_{8}$ BOARD SHARE $+\alpha_{9}$ OUTSIDERS $+\alpha_{10}$ CEO FOUNDER $+\alpha_{11}$ AGE $+\alpha_{12}$ TENURE $+\alpha_{13}$ DIRECTOR SHARE $+\alpha_{14}$ OTHER CEO $+\alpha_{15}$ OTHER DIRECTORSHIPS $+\alpha_{16}$ FIN EXPERT $+\alpha_{17}$ DIR AFTER CEO $+\alpha_{18}$ DIR SELLER $+\varepsilon_{\mathrm{i}}$ )

\begin{tabular}{|c|c|c|c|c|c|c|c|c|}
\hline & Model 1 & & Model 2 & & Model 3 & & Model 4 & \\
\hline Constant & -1.87 & $(-2.61)^{\star \star \star}$ & -2.40 & $(-2.99)^{\star \star \star}$ & -2.04 & $(-2.69)^{\star \star \star}$ & -1.32 & $(-1.73)^{\star}$ \\
\hline AUDIT COMM & -0.25 & $(-1.12)$ & -0.07 & $(-0.44)$ & -0.16 & $(-0.68)$ & -0.27 & $(-1.24)$ \\
\hline $\begin{array}{l}\text { DURATION } \\
\text { AUDIT COMM X } \\
\text { DURATION }\end{array}$ & $\begin{array}{l}0.04 \\
0.05\end{array}$ & $\begin{array}{l}(2.13)^{\star \star} \\
(2.23)^{\star \star}\end{array}$ & & & & & $\begin{array}{l}0.06 \\
0.06\end{array}$ & $\begin{array}{l}(2.29)^{\star \star} \\
(2.90)^{\star \star}\end{array}$ \\
\hline $\begin{array}{l}\text { MAGNITUDE } \\
\text { AUDIT COMM X } \\
\text { MAGNITUDE }\end{array}$ & & & $\begin{array}{l}0.99 \\
1.94\end{array}$ & $\begin{array}{l}(2.82)^{\star \star \star} \\
(2.03)^{\star \star}\end{array}$ & & & & \\
\hline $\begin{array}{l}\text { REST QTRS SERVED } \\
\text { AUDIT COMM X REST } \\
\text { QTRS SERVED }\end{array}$ & & & & & $\begin{array}{l}0.04 \\
0.06\end{array}$ & $\begin{array}{l}(2.02)^{\star \star} \\
(2.24)^{\star \star}\end{array}$ & & \\
\hline PERFORMANCE & -0.32 & $(-2.19)^{\star \star \star}$ & -0.34 & $(-1.98)^{\star \star}$ & -0.31 & $(-2.06)^{\star \star}$ & -0.48 & $(-2.76)^{\star \star \star}$ \\
\hline$S I Z E$ & -0.00 & $(-0.02)$ & -0.00 & $(-0.97)$ & -0.00 & $(-0.28)$ & -0.00 & $(-0.49)$ \\
\hline CEO TURNOVER & 0.63 & $(3.99)^{\star \star \star}$ & 0.67 & $(4.01)^{\star \star \star}$ & 0.62 & $(4.15)^{\star \star \star}$ & & \\
\hline BOARD SIZE & 0.04 & $(0.80)$ & 0.08 & $(1.47)$ & 0.05 & (1.06) & -0.01 & $(-0.40)$ \\
\hline BOARD SHARE & 0.01 & $(1.86)^{\star}$ & 0.01 & $(1.44)$ & 0.01 & $(1.79)^{\star}$ & 0.00 & $(0.76)$ \\
\hline OUTSIDERS & 0.00 & $(0.06)$ & 0.00 & $(0.60)$ & -0.00 & $(-0.07)$ & 0.00 & $(0.02)$ \\
\hline CEO FOUNDER & 0.01 & $(0.04)$ & 0.13 & $(0.50)$ & -0.02 & $(-0.07)$ & -0.10 & $(-0.34)$ \\
\hline$A G E$ & 0.02 & $(1.79)^{\star}$ & 0.01 & $(1.84)^{\star}$ & 0.01 & $(1.89)^{\star}$ & 0.02 & $(1.96)^{\star \star}$ \\
\hline TENURE & -0.03 & $(-1.81)^{\star}$ & -0.02 & $(-1.88)^{\star}$ & -0.03 & $(-1.98)^{\star \star}$ & -0.05 & $(-2.51)^{\star \star}$ \\
\hline DIRECTOR SHARE & -0.01 & $(-0.88)$ & -0.01 & $(-1.04)$ & -0.02 & $(-1.16)$ & -0.00 & $(-0.09)$ \\
\hline $\begin{array}{l}\text { OTHER CEO } \\
\text { OTHER }\end{array}$ & -0.10 & $(-0.47)$ & -0.07 & $(-0.36)$ & -0.07 & $(-0.41)$ & -0.08 & $(-0.44)$ \\
\hline DIRECTORSHIPS & -0.07 & $(-2.06)^{\star \star}$ & -0.08 & $(-1.92)^{\star}$ & -0.07 & $(-1.94)^{\star}$ & -0.05 & $(-1.72)^{\star}$ \\
\hline FIN EXPERT & -0.03 & $(-0.17)$ & -0.05 & $(-0.28)$ & -0.03 & $(-0.17)$ & -0.04 & $(-0.18)$ \\
\hline DIR AFTER CEO & -0.20 & $(-0.79)$ & -0.11 & $(-0.41)$ & -0.15 & $(-0.56)$ & -0.17 & $(-0.68)$ \\
\hline DIR SELLER & 0.22 & $(1.86)^{\star}$ & 0.25 & $(1.97)^{\star \star}$ & 0.26 & $(2.08)^{\star \star}$ & 0.18 & $(1.90)^{\star}$ \\
\hline Pseudo R2 & 0.1876 & & 0.1948 & & 0.1764 & & 0.1340 & \\
\hline $\mathrm{Y}=1$ correctly classified & $66 \%$ & & $64 \%$ & & $64 \%$ & & $60 \%$ & \\
\hline $\begin{array}{l}Y=0 \text { correctly classified } \\
\text { Overall Correctly }\end{array}$ & $76 \%$ & & $75 \%$ & & $72 \%$ & & $70 \%$ & \\
\hline Classified & $71 \%$ & & $70 \%$ & & $68 \%$ & & $65 \%$ & \\
\hline
\end{tabular}




\section{Table 7}

Firm-Level Board and Audit Committee Turnover Income-Decreasing Restatements

The table presents the results of firm level OLS regressions for the models given. The $t$-statistics (in parentheses) are robust to heteroskedasticity. Model 1 measures restatement severity by DURATION and model 2 measures it by MAGNITUDE. Please refer to Table 1 for variable definitions. $\mathrm{N}$ is 264 for all models. *, ** and *** indicates significance at $10 \%, 5 \%$, and $1 \%$ levels (two-tailed).

\begin{tabular}{l|rl|cl}
\hline & \multicolumn{3}{|c|}{ Model 1 } & Model 2 \\
\hline Panel A: \% AC Turnover & \multicolumn{1}{|c}{$\boldsymbol{f}$ (Restatement Severity, Control Variables) } \\
\hline Constant & 25.96 & $(2.12)^{\star \star}$ & 29.76 & $(2.88)^{\star \star \star}$ \\
SEVERITY & 1.34 & $(2.93)^{\star \star \star}$ & 28.99 & $(3.89)^{\star \star \star}$ \\
PERFORMANCE & -8.04 & $(-2.57)^{\star \star}$ & -7.86 & $(-2.05)^{\star \star}$ \\
SIZE & 1.47 & $(0.85)$ & 2.41 & $(1.40)$ \\
CEO TURNOVER & 20.16 & $(3.53)^{\star \star \star}$ & 22.01 & $(4.09)^{\star \star \star}$ \\
BOARD SIZE & -0.02 & $(-0.02)$ & -0.01 & $(-0.01)$ \\
BOARD SHARE & 0.23 & $(1.95)^{\star}$ & 0.23 & $(1.94)^{\star}$ \\
OUTSIDERS & -0.02 & $(-0.16)$ & -0.07 & $(-0.49)$ \\
CEO FOUNDER & -0.01 & $(-0.23)$ & 0.06 & $(0.56)$ \\
Adj. R & 0.1961 & & 0.2028 & \\
\hline
\end{tabular}

Panel B: [\% AC Turnover - \% Non AC Turnover] = f (Restatement Severity, Control Variables)

\begin{tabular}{l|cl|cl}
\hline Constant & 21.81 & $(1.62)$ & 27.66 & $(1.93)^{\star}$ \\
SEVERITY & 0.60 & $(2.04)^{\star \star}$ & 21.84 & $(2.03)^{\star \star}$ \\
PERFORMANCE & -12.44 & $(-2.15)^{\star \star}$ & -11.81 & $(-2.08)^{\star \star}$ \\
SIZE & 4.79 & $(2.40)^{\star \star}$ & 5.37 & $(2.70)^{\star \star}$ \\
CEO TURNOVER & 10.54 & $(2.12)^{\star \star}$ & 9.62 & $(1.92)^{\star}$ \\
BOARD SIZE & -3.01 & $(-1.62)$ & -3.26 & $(-1.55)$ \\
BOARD SHARE & 0.24 & $(1.64)$ & 0.25 & $(1.75)^{\star}$ \\
OUTSIDERS & -0.26 & $(-1.37)$ & -0.28 & $(-1.46)$ \\
CEO FOUNDER & 0.04 & $(0.57)$ & -0.02 & $(-0.15)$ \\
Adj. R & 0.1126 & & 0.1245 & \\
\hline
\end{tabular}




\section{Table 8 \\ Loss of Board Position in Restating Company for Income-Increasing and Technical Restatements}

The table presents estimates from a logit regression of equation (1). $\mathrm{Y}=1$ if the director leaves the board. Models 1 and 2 present results for the Income-increasing restatements sample, and models 3 and 4 present results from the Technical restatements sample. The $t$-statistics (in parentheses) are robust to heteroskedasticity and are adjusted for clustering by company. Models 1 and 3 measure SEVERITY by DURATION, and models 2 and 4 measure SEVERITY by MAGNITUDE. Please refer to Table 1 for variable definitions. $*$, **, *** indicates significance at $10 \%, 5 \%$, and $1 \%$ levels (two-tailed).

$\operatorname{Pr}(\mathrm{Y}=1)=\mathrm{F}\left(\alpha_{0}+\alpha_{1}\right.$ AUDIT COMM $+\alpha_{2}$ SEVERITY $+\alpha_{3}$ AUDIT COMM X SEVERITY $+\alpha_{4}$ PERFORMANCE $+\alpha_{5}$ SIZE + $\alpha_{6}$ CEO TURNOVER $+\alpha_{7}$ BOARD SIZE $+\alpha_{8}$ BOARD SHARE $+\alpha_{9}$ OUTSIDERS $+\alpha_{10}$ CEO FOUNDER $+\alpha_{11}$ AGE $+\alpha_{12}$ TENURE $+\alpha_{13}$ DIRECTOR SHARE $+\alpha_{14}$ OTHER CEO $+\alpha_{15}$ OTHER DIRECTORSHIPS $+\alpha_{16}$ FIN EXPERT $+\alpha_{17}$ DIR_AFTER_CEO $+\alpha_{18}$ DIR SELLER $\left.+\varepsilon_{\mathrm{i}}\right)$

\begin{tabular}{|c|c|c|c|c|c|c|c|c|}
\hline \multirow[b]{3}{*}{ Constant } & \multicolumn{4}{|c|}{ Income-Increasing Sample } & \multicolumn{4}{|c|}{ Technical Sample } \\
\hline & \multicolumn{2}{|l|}{ Model 1} & \multicolumn{2}{|l|}{ Model 2} & \multicolumn{2}{|l|}{ Model 3} & \multicolumn{2}{|l|}{ Model 4} \\
\hline & -0.38 & $(-0.90)$ & -2.00 & $(-0.71)$ & -2.64 & $(-1.99)^{\star \star}$ & -3.02 & $(-1.49)$ \\
\hline AUDIT COMM & -1.11 & $(-1.86)^{\star}$ & -0.41 & $(-0.65)$ & -0.42 & $(-0.65)$ & 0.33 & $(0.82)$ \\
\hline DURATION & 0.01 & $(0.28)$ & & & -0.08 & $(-0.95)$ & & \\
\hline AUDIT COMM X DURATION & 0.10 & $(2.00)^{\star \star}$ & & & 0.21 & $(0.19)$ & & \\
\hline MAGNITUDE & & & 3.68 & $(1.88)^{\star}$ & & & 2.25 & $(0.17)$ \\
\hline AUDIT COMM $\times$ MAGNITUDE & & & 4.12 & $(1.70)^{\star}$ & & & -1.16 & $(-0.26)$ \\
\hline PERFORMANCE & -0.40 & $(-1.50)$ & -0.75 & $(-2.0)^{\star \star}$ & -0.56 & $(-2.32)^{\star \star}$ & -0.32 & $(-2.62)^{\star \star}$ \\
\hline SIZE & 0.00 & $(0.55)$ & 0.00 & $(0.22)$ & -0.01 & $(-1.97)^{\star \star}$ & -0.00 & $(-1.50)$ \\
\hline CEO TURNOVER & 0.10 & $(0.55)$ & 0.08 & $(0.21)$ & 1.21 & $(1.52)$ & 0.68 & $(0.72)$ \\
\hline BOARD SIZE & -0.13 & $(-2.02)^{\star \star}$ & -0.08 & $(-0.98)$ & 0.17 & $(1.74)^{\star}$ & 0.03 & $(0.27)$ \\
\hline BOARD SHARE & 0.03 & $(2.57)^{\star \star}$ & 0.02 & $(2.14)^{\star \star}$ & -0.00 & $(-0.17)$ & 0.01 & $(0.79)$ \\
\hline OUTSIDERS & 0.01 & $(1.51)$ & 0.00 & $(0.87)$ & 0.21 & $(0.71)$ & 0.57 & $(0.36)$ \\
\hline CEO FOUNDER & 0.06 & $(0.08)$ & -0.05 & $(-0.36)$ & 0.02 & $(0.56)$ & 0.01 & $(0.68)$ \\
\hline$A G E$ & 0.00 & $(0.31)$ & 0.00 & $(0.44)$ & 0.01 & $(0.21)$ & -0.01 & $(-0.10)$ \\
\hline TENURE & -0.06 & $(-1.78)^{\star}$ & -0.05 & $(-1.73)^{\star}$ & 0.03 & $(1.86)^{\star}$ & 0.01 & $(1.59)$ \\
\hline DIRECTOR SHARE & -0.05 & $(-1.90)^{*}$ & -0.17 & $(-2.32)^{\star \star}$ & -0.01 & $(-0.29)$ & -0.01 & $(-0.06)$ \\
\hline OTHER CEO & -0.95 & $(-2.34)^{\star \star}$ & -0.72 & $(-1.80)^{\star}$ & 1.15 & $(0.99)$ & 1.05 & $(0.96)$ \\
\hline OTHER DIRECTORSHIPS & -0.10 & $(-0.54)$ & -0.03 & $(-0.21)$ & 0.05 & $(0.36)$ & 0.02 & $(0.14)$ \\
\hline FIN EXPERT & -0.24 & $(-0.78)$ & -0.41 & $(-0.98)$ & -1.91 & $(-1.02)$ & -1.88 & $(-1.22)$ \\
\hline DIR AFTER CEO & -0.08 & $(-0.65)$ & -0.07 & $(-0.58)$ & 0.09 & $(1.01)$ & 0.07 & $(0.80)$ \\
\hline DIR SELLER & 0.09 & $(1.19)$ & 0.02 & $(0.56)$ & 0.01 & $(0.23)$ & -0.02 & $(-0.23)$ \\
\hline Pseudo $R^{2}$ & 0.1310 & & 0.126 & & 0.1132 & & 0.0812 & \\
\hline$N$ & 332 & & 332 & & 412 & & 412 & \\
\hline$Y=1$ correctly classified & $81 \%$ & & $82 \%$ & & $55 \%$ & & $51 \%$ & \\
\hline$Y=0$ correctly classified & $75 \%$ & & $74 \%$ & & $91 \%$ & & $90 \%$ & \\
\hline Overall correctly classified & $77 \%$ & & $76 \%$ & & $84 \%$ & & $83 \%$ & \\
\hline
\end{tabular}




\section{Figure 3 \\ Other Directorships}

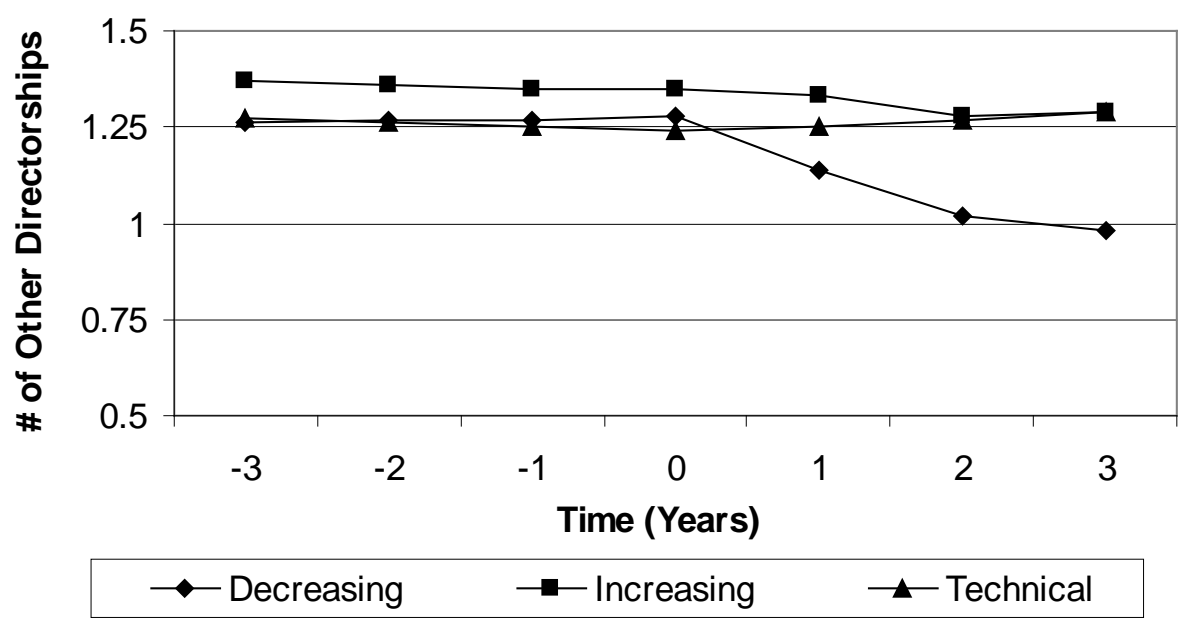

FIG. 3-Other directorships. The graph shows the average number of other directorships held by directors of the restating companies. The legend below identifies the plots. "Decreasing" refers to the incomedecreasing restatements sample, "Increasing" refers to the income-increasing restatements sample and "Technical" refers to the technical restatements sample. The $x$-axis is the time (years) relative to the restatement announcement year. The $y$-axis gives the average number of other directorships. Year 0 is the year of the restatement announcement.

Figure 4

\section{Other Directorships - Income Decreasing Restatement Sample}

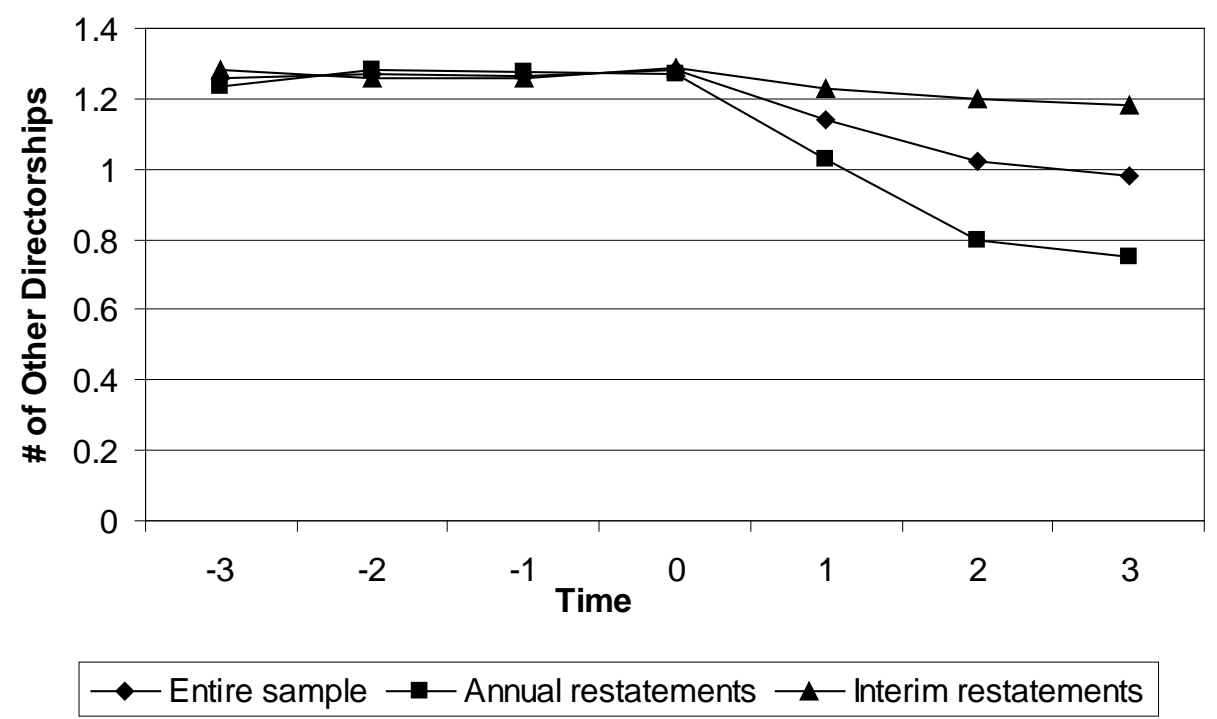

FIG. 4-Other directorships in the income-decreasing restatement sample. The graph shows the average number of other directorships held by directors of the income-decreasing restatements sample. The legend below identifies the plots. "Interim restatements" refers to the sample of companies that issue quarterly restatements, "Annual restatements" refers to companies that restate audited annual financials, and "Total sample" refers to the entire sample of income-decreasing restatements. The $x$-axis is the time (years) relative to the restatement announcement year. The $y$-axis gives the average number of other directorships. Year 0 is the year of the restatement announcement. 


\section{Table 9}

\section{Loss in Other Board Positions-Income-Decreasing Restatements}

Estimates from an OLS regression of loss in the number of other directorships, on firm level and director level variables. The $t$-statistics (in parentheses) are robust to heteroskedasticity and are adjusted for clustering by company. Model 1 measures SEVERITY by DURATION, model 2 measures SEVERITY by MAGNITUDE, and model 3 measures SEVERITY by REST QTRS SERVED. Please refer to Table 1 for variable definitions. $\mathrm{N}=1,272$ for all the models. *, **, *** indicates significance at $10 \%, 5 \%$, and $1 \%$ levels (two-tailed).

OTHER DIRECTOR LOSS $=\beta_{0}+\beta_{1}$ AUDIT COMM $+\beta_{2}$ SEVERITY $+\beta_{3}$ AUDIT COMM X SEVERITY + $\beta_{4}$ PERFORMANCE $+\beta_{5}$ SIZE $+\beta_{6}$ AGE $+\beta_{7}$ TENURE $+\beta_{8}$ OTHER CEO + $\beta_{9}$ OTHER DIRECTORSHIPS $+\beta_{10}$ FIN EXPERT $+\beta_{11}$ DIRECTOR DEPARTURE $+\beta_{12}$ DIR SELLER $+\eta_{\text {I }}$

\begin{tabular}{|c|c|c|c|c|c|c|}
\hline & Model 1 & & Model 2 & & Model 3 & \\
\hline Constant & -0.79 & $(-3.06)^{\star \star \star}$ & -0.77 & $(-3.13)^{\star \star \star}$ & -0.37 & $(-2.91)^{\star \star \star}$ \\
\hline AUDIT COMM & -0.08 & $(-0.65)$ & -0.05 & $(-0.40)$ & 0.06 & $(0.75)$ \\
\hline DURATION & 0.03 & $(2.05)^{\star \star}$ & & & & \\
\hline AUDIT COMM X DURATION & 0.03 & $(2.28)^{\star \star}$ & & & & \\
\hline MAGNITUDE & & & 0.41 & $(2.90)^{\star \star \star}$ & & \\
\hline AUDIT COMM X MAGNITUDE & & & 0.34 & $(2.09)^{\star \star}$ & & \\
\hline REST QTRS SERVED & & & & & 0.03 & $(1.83)^{\star}$ \\
\hline AUDIT COMM X REST QTRS & & & & & & \\
\hline SERVED & & & & & 0.04 & $(2.41)^{\star \star}$ \\
\hline PERFORMANCE & -0.06 & $(-0.77)$ & -0.06 & $(-0.86)$ & -0.05 & $(-0.66)$ \\
\hline SIZE & -0.00 & $(-1.13)$ & -0.00 & $(-1.34)$ & -0.00 & $(-2.20)^{\star \star}$ \\
\hline$A G E$ & 0.01 & $(1.93)^{\star}$ & 0.01 & $(2.10)^{\star}$ & 0.01 & $(1.71)^{*}$ \\
\hline TENURE & 0.00 & $(0.74)$ & 0.00 & $(0.34)$ & 0.00 & $(0.89)$ \\
\hline OTHER CEO & -0.26 & $(-2.54)^{\star \star}$ & -0.25 & $(-2.45)^{\star \star}$ & -0.26 & $(-2.51)^{\star \star}$ \\
\hline OTHER DIRECTORSHIPS & 0.45 & $(8.50)^{\star \star \star}$ & 0.46 & $(8.73)^{\star \star \star}$ & 0.41 & $(8.72)^{\star \star \star}$ \\
\hline FIN EXPERT & 0.14 & $(1.76)^{\star}$ & 0.14 & $(1.77)^{\star}$ & 0.15 & $(1.66)^{\star}$ \\
\hline DIRECTOR DEPARTURE & 0.36 & $(3.42)^{\star \star \star}$ & 0.37 & $(3.62)^{\star \star \star}$ & 0.38 & $(3.68)^{\star \star \star}$ \\
\hline DIR SELLER & 0.12 & $(2.17)^{\star \star}$ & 0.09 & $(2.08)^{\star \star}$ & 0.14 & $(1.94)^{*}$ \\
\hline Adj. $R^{2}$ & 0.3970 & & 0.3811 & & 0.3924 & \\
\hline
\end{tabular}


TABLE 10

Loss in Other Board Positions: Firm-Level Analysis of Income-Decreasing Restatements

The table presents the results of firm-level OLS regressions for the models given. The $t$-statistics (in parentheses) are robust to heteroskedasticity. Model 1 measures SEVERITY by DURATION and model 2 measures SEVERITY by MAGNITUDE. Please refer to table 1 for variable definitions. $\mathrm{N}$ is 264 for all models. ${ }^{*}, * *$ and $* * *$ indicates significance at $10 \%, 5 \%$, and $1 \%$ levels (two-tailed).

\begin{tabular}{|c|c|c|c|c|}
\hline & \multicolumn{2}{|c|}{ Model 1} & \multicolumn{2}{|c|}{ Model 2} \\
\hline \multicolumn{5}{|c|}{ Panel A: (AC Other Director Loss) = f (Restatement Severity, Control Variables) } \\
\hline Constant & -0.92 & $(-4.15)^{\star \star \star}$ & -0.26 & $(-1.93)^{\star}$ \\
\hline SEVERITY & 0.17 & $(4.56)^{\star \star \star}$ & 3.12 & $(2.64)^{\star \star}$ \\
\hline PERFORMANCE & 0.04 & $(0.28)$ & -0.03 & $(-0.35)$ \\
\hline SIZE & -0.16 & $(-0.06)$ & -0.16 & $(-0.46)$ \\
\hline TOTAL OTHER DIRECTORSHIPS & 0.20 & $(4.42)^{\star \star \star}$ & 0.22 & $(5.12)^{\star \star \star}$ \\
\hline Adj. $R^{2}$ & \multicolumn{2}{|l|}{0.3622} & \multicolumn{2}{|l|}{0.3840} \\
\hline \multirow[t]{2}{*}{$N$} & \multicolumn{2}{|l|}{264} & \multicolumn{2}{|l|}{264} \\
\hline & \multicolumn{2}{|l|}{ Model 1} & \multicolumn{2}{|l|}{ Model 2} \\
\hline \multicolumn{5}{|c|}{$\begin{aligned} \text { Panel B: [AC Other Director Loss - Non AC Other Director Loss] }= & f(\text { Restatement Severity, } \\
& \text { Control Variables })\end{aligned}$} \\
\hline Constant & -0.84 & $(-2.30)^{\star \star}$ & 0.07 & $(0.56)$ \\
\hline SEVERITY & 0.15 & $(3.75)^{\star \star \star}$ & 1.95 & $(2.25)^{\star \star}$ \\
\hline PERFORMANCE & 0.11 & $(0.92)$ & 0.06 & $(0.52)$ \\
\hline SIZE & 0.01 & $(0.09)$ & 0.00 & $(0.25)$ \\
\hline TOTAL OTHER DIRECTORSHIPS & 0.05 & $(0.59)$ & 0.03 & $(0.42)$ \\
\hline Adj. $R^{2}$ & 0.0969 & & 0.0512 & \\
\hline$N$ & 264 & & 264 & \\
\hline
\end{tabular}




\section{Table 11}

Loss in Other Board Positions Income-Increasing and Technical Restatements Sample

Estimates from an OLS regression of equation (2). Models 1 and 2 present results for the incomeincreasing restatements sample, and models 3 and 4 present results for the technical restatements sample. The $t$-statistics (in parentheses) are robust to heteroskedasticity and are adjusted for clustering by company. Models 1 and 3 measure SEVERITY by DURATION, and models 2 and 4 measure SEVERITY by the MAGNITUDE. Please refer to table 1 for variable definitions. *, **, *** indicate two-sided significance at $10 \%, 5 \%$, and $1 \%$ levels respectively.

OTHER DIRECTOR LOSS $=\beta_{0}+\beta_{1}$ AUDIT COMM $+\beta_{2}$ SEVERITY $+\beta_{3}$ AUDIT COMM X SEVERITY + $\beta_{4}$ PERFORMANCE $+\beta_{5}$ SIZE $+\beta_{6}$ AGE $+\beta_{7}$ TENURE $+\beta_{8}$ OTHER CEO + $\beta_{9}$ OTHER DIRECTORSHIPS $+\beta_{10}$ FIN EXPERT $+\beta_{11}$ DIRECTOR DEPARTURE $+\beta_{12}$ DIR SELLER $+\eta_{\text {I }}$

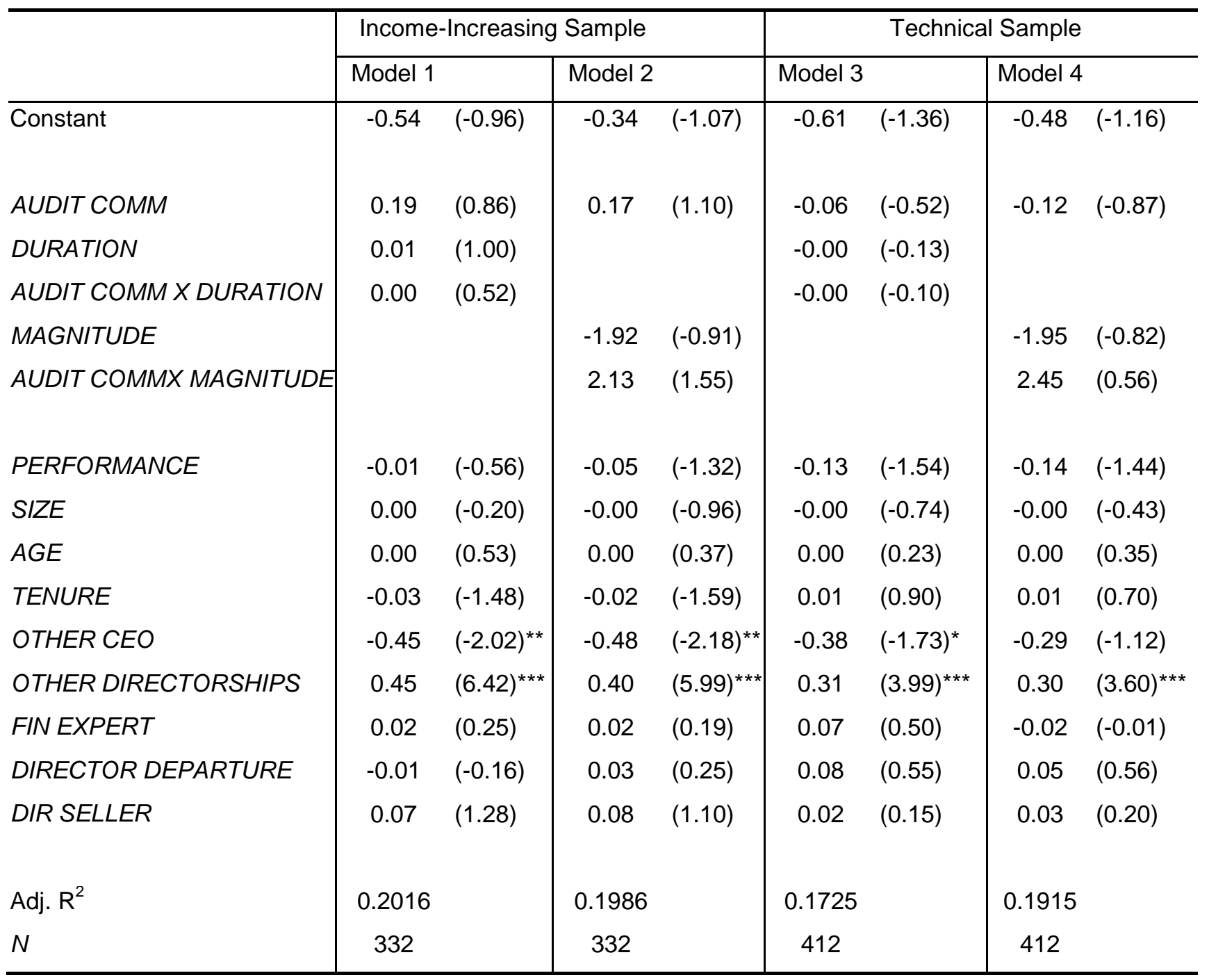


Table 12

\section{Selected Summary Statistics for Sample and Control Firms}

The table reports various descriptive statistics for the sample of income-decreasing restatement companies and their year-, industry-, and performance-matched control firms. TOTAL OTHER DIRECTORSHIPS is the sum of other directorships for all directors in the company, and TOTAL LOSS IN OTHER DIRECTORSHIPS is the loss cumulated over all the directors of the company. All other variables are defined in table 1.

\begin{tabular}{l|l|l|l|l|l|l}
\hline & \multicolumn{3}{|c|}{ Mean } & \multicolumn{3}{c}{ Median } \\
\hline & $\begin{array}{l}\text { Income - } \\
\text { Decreasing } \\
\text { Restatements }\end{array}$ & $\begin{array}{l}\text { Control } \\
\text { Sample }\end{array}$ & $\begin{array}{l}p- \\
\text { value }\end{array}$ & $\begin{array}{l}\text { Income - } \\
\text { Decreasing } \\
\text { Restatements }\end{array}$ & $\begin{array}{l}\text { Control } \\
\text { Sample }\end{array}$ & $\begin{array}{l}\text { Wilcoxon } \\
p \text { value }\end{array}$ \\
\hline
\end{tabular}

Panel B: Subsample of 51 firms where both the restating and matched firm experienced CEO

\section{turnover}

PERFORMANCE

SIZE (\$millions)

AUDITOR TURNOVER

OUTSIDE DIRECTOR

TURNOVER

AUDIT COMM TURNOVER

TOTAL OTHER

DIRECTORSHIPS

TOTAL LOSS IN OTHER

DIRECTORSHIPS

${ }^{a}$ For the matched pairs $t$-test (two-tailed).

${ }^{b}$ For the Wilcoxon signed ranks test (two-tailed).

\begin{tabular}{l|l|l|l|l|l}
-0.291 & -0.301 & 0.993 & $-44.01 \%$ & $-44.89 \%$ & 0.754 \\
800 & 552 & 0.117 & 163 & 149 & 0.02 \\
$55.5 \%$ & $22.2 \%$ & 0.0032 & 1 & 0 & 0.0047 \\
$58.6 \%$ & $44.4 \%$ & 0.035 & $50.0 \%$ & $40.0 \%$ & 0.052 \\
$65.0 \%$ & $39.1 \%$ & 0.001 & $66.6 \%$ & $33.3 \%$ & $<.0001$ \\
6.44 & 6.58 & 0.914 & 5 & 4 & 0.943 \\
2.58 & 1.11 & 0.015 & 1 & 0.5 & 0.04 \\
\hline
\end{tabular}




\section{Table 13}

Firm-Level Outside Director and Audit Committee Turnover Income-Decreasing Restatements and Control Sample

The table presents the results of firm level OLS regressions for equation (3). The t-statistics (in parentheses) are robust to heteroskedasticity. Please refer to table 1 for variable definitions. Model 1 expresses the constant as SEVERITY, model 2 measures SEVERITY by DURATION and model 3 by MAGNITUDE. Control firms get the value 0 for DURATION and MAGNITUDE. *, ** and *** indicate two sided significance at $10 \%, 5 \%$, and $1 \%$ levels (two-tailed).

[\% AC Turnover - \% Non AC Turnover] Restatement - Control $=\mathrm{f}($ Restatement Severity, $\Delta$ Control Variables $)$

\begin{tabular}{|c|c|c|c|c|c|c|}
\hline & \multicolumn{2}{|l|}{ Model1 } & \multicolumn{2}{|l|}{ Model 2} & \multicolumn{2}{|l|}{ Model 3} \\
\hline \multicolumn{7}{|c|}{ Panel A: Entire sample of 264 matched pair of restating and control firms. } \\
\hline Constant & & & 2.20 & $(0.76)$ & 2.25 & $(0.54)$ \\
\hline RESTATE SEVERITY & 6.01 & $(2.07)^{\star \star}$ & 2.14 & $(2.56)^{\star \star}$ & 38.14 & $(3.32)^{\star \star \star}$ \\
\hline PERFORMANCE & 0.82 & $(0.09)$ & 1.74 & $(0.55)$ & -0.56 & $(-0.13)$ \\
\hline SIZE & -0.00 & $(-0.20)$ & 0.00 & $(0.02)$ & 0.00 & $(0.10)$ \\
\hline CEO TURNOVER & 8.45 & $(2.04)^{\star \star}$ & 7.38 & $(1.86)^{\star}$ & 6.90 & $(1.98)^{\star \star}$ \\
\hline BOARD SIZE & 0.94 & $(0.81)$ & 1.07 & $(0.92)$ & 0.98 & $(0.85)$ \\
\hline BOARD SHARE & -0.20 & $(-1.27)$ & -0.18 & $(-1.22)$ & -0.20 & $(-1.31)$ \\
\hline OUTSIDERS & -15.57 & $(-0.78)$ & -14.51 & $(-0.85)$ & -15.69 & $(-0.92)$ \\
\hline CEO FOUNDER & -1.53 & $(-0.24)$ & 1.44 & $(0.52)$ & -1.88 & $(-0.54)$ \\
\hline Adj. $\mathrm{R}^{2}$ & 0.0601 & & 0.1786 & & 0.1689 & \\
\hline \multicolumn{7}{|c|}{ Panel B: Subsample of 51 firms where both the restating and matched firm experienced CEO } \\
\hline Constant & & & 14.51 & $(1.01)$ & 9.07 & $(0.84)$ \\
\hline RESTATE SEVERITY & 18.34 & $(2.30)^{\star \star}$ & 0.56 & $(3.62)^{\star \star \star}$ & 56.69 & $(2.60)^{\star \star}$ \\
\hline PERFORMANCE & -10.41 & $(-1.02)$ & -7.30 & $(-0.86)$ & -4.46 & $(-0.47)$ \\
\hline SIZE & -0.00 & $(-0.16)$ & 0.00 & $(0.09)$ & 0.00 & $(0.00)$ \\
\hline BOARD SIZE & -3.50 & $(-1.09)$ & -3.04 & $(-1.11)$ & -3.12 & $(-1.04)$ \\
\hline BOARD SHARE & 0.00 & $(0.81)$ & 0.47 & $(1.07)$ & 0.00 & $(0.80)$ \\
\hline OUTSIDERS & -31.00 & $(-0.57)$ & -32.38 & $(-0.71)$ & -26.03 & $(-0.52)$ \\
\hline CEO FOUNDER & -23.74 & $(-0.88)$ & -17.73 & $(-0.78)$ & -19.37 & $(-0.78)$ \\
\hline Adj. $R^{2}$ & 0.0924 & & 0.2274 & & 0.1134 & \\
\hline
\end{tabular}


TABLE 14

Loss in Other Board Positions for Income-Decreasing Restatements and Control Sample

The table presents the results of firm level OLS regressions for equation (4). The t-statistics (in parentheses) are robust to heteroskedasticity. Model 1 expresses the constant as SEVERITY. Model 2 measures SEVERITY by DURATION and model 3 measures SEVERITY by MAGNITUDE. Control firms get the value 0 for DURATION and MAGNITUDE. Please refer to table 1 for variable definitions. $\mathrm{N}$ $=264$ for all models. ${ }^{*},{ }^{* *}$ and $* * *$ indicate two sided significance at $10 \%, 5 \%$, and $1 \%$ levels (two-tailed).

[AC Other Director Loss - Non-AC Other Director Loss] Restatement-Control $=f($ Restatement Severity, $\Delta$ Control Variables $)$

\begin{tabular}{|c|c|c|c|c|c|c|}
\hline & \multicolumn{2}{|l|}{ Model 1} & \multicolumn{2}{|c|}{ Model 2} & \multicolumn{2}{|c|}{ Model 3} \\
\hline Constant & & & -0.28 & $(-0.70)$ & 0.14 & $(0.40)$ \\
\hline SEVERITY & 0.33 & $(3.34)^{\star \star \star}$ & 0.10 & $(2.56)^{\star \star}$ & 2.32 & $(2.37)^{\star \star}$ \\
\hline PERFORMANCE & 0.05 & $(0.23)$ & 0.04 & $(0.15)$ & 0.11 & $(0.63)$ \\
\hline SIZE & -0.00 & $(-1.22)$ & -0.00 & $(-1.61)$ & -0.00 & $(-1.23)$ \\
\hline $\begin{array}{l}\text { TOTAL OTHER } \\
\text { DIRECTORSHIPS }\end{array}$ & 0.16 & $(5.75)^{\star \star \star}$ & 0.17 & $(5.94)^{\star \star \star}$ & 0.16 & $(5.67)^{\star \star \star}$ \\
\hline Adj. $R^{2}$ & 0.1496 & & 0.1678 & & 0.1728 & \\
\hline$N$ & 264 & & 264 & & 264 & \\
\hline
\end{tabular}

